\title{
INDEPENDENT VERIFICATION SURVEY REPORT FOR THE OPERABLE UNIT-1 LANDFILL MIAMISBURG CLOSURE PROJECT MIAMISBURG, OHIO
}

\author{
P.C. Weaver
}

Prepared for the

U.S. Department of Energy

\section{O R I S E}


The Oak Ridge Institute for Science and Education (ORISE) is a U.S. Department of Energy facility focusing on scientific initiatives to research health risks from occupational hazards, assess environmental cleanup, respond to radiation medical emergencies, support national security and emergency preparedness, and educate the next generation of scientists. ORISE is managed by Oak Ridge Associated Universities. Established in 1946, ORAU is a consortium of 96 colleges and universities.

\section{NOTICES}

The opinions expressed herein do not necessarily reflect the opinions of the sponsoring institutions of Oak Ridge Associated Universities.

This report was prepared as an account of work sponsored by the United States Government. Neither the United States Government nor the U.S. Department of Energy, nor any of their employees, makes any warranty, expressed or implied, or assumes any legal liability or responsibility for the accuracy, completeness, or usefulness of any information, apparatus, product, or process disclosed, or represents that its use would not infringe on privately owned rights. Reference herein to any specific commercial product, process, or service by trade name, mark, manufacturer, or otherwise, does not necessarily constitute or imply its endorsement or recommendation, or favor by the U.S. Government or any agency thereof. The views and opinions of authors expressed herein do not necessarily state or reflect those of the U.S. Government or any agency thereof. 


\title{
INDEPENDENT VERIFICATION SURVEY REPORT FOR THE OPERABLE UNIT-1 LANDFILL MIAMISBURG CLOSURE PROJECT MIAMISBURG, OHIO
}

\author{
Prepared by \\ P. C. Weaver \\ Oak Ridge Institute for Science and Education \\ Oak Ridge, Tennessee 37831-0117 \\ Prepared for the \\ U.S. Department of Energy
}

FINAL REPORT

March 2008

This report is based on work performed by the Oak Ridge Institute for Science and Education Under contract number DE-AC05-06OR23100 with the Department of Energy 


\section{INDEPENDENT VERIFICATION SURVEY REPORT \\ FOR THE OPERABLE UNIT-1 \\ MIAMISBURG CLOSURE PROJECT \\ MIAMISBURG, OHIO}

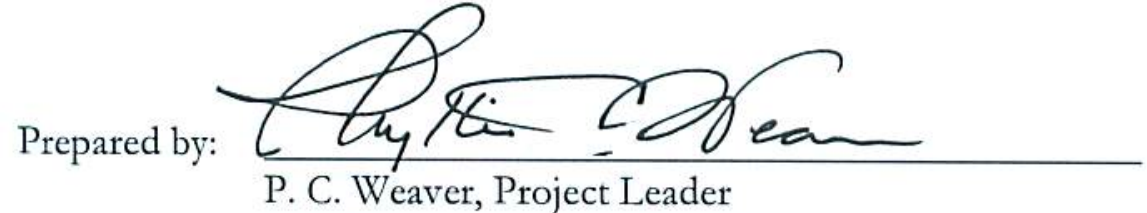

Date: $3 / 14 / 08$

Reviewed by:

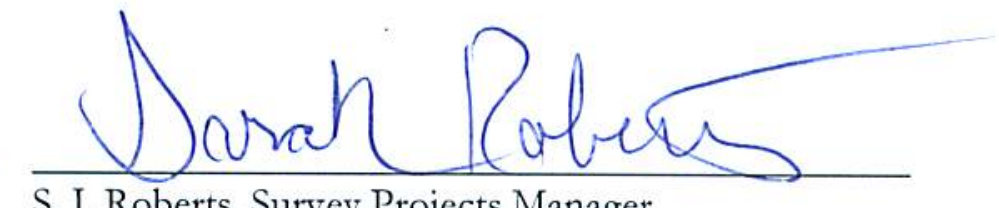

S. J. Roberts, Survey Projects Manager

Date: $3 / 14 / 08$

Reviewed by: $\frac{\text { Nade o. href for }}{\text { R. D. Condra, Laboratory Manager }}$

Date: 3/14/08

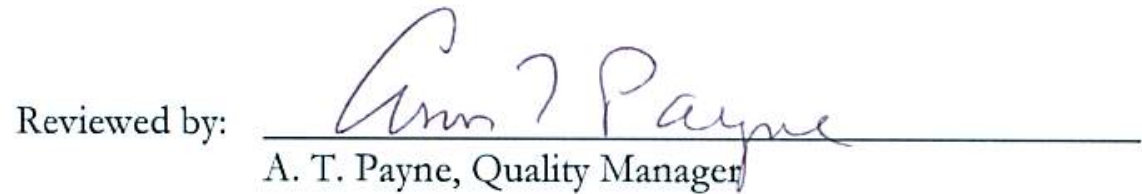

Date: $3 / 14 / 08$ 


\section{ACKNOWLEDGMENTS}

The author would like to acknowledge the significant contributions of the following staff members:

PROJECT STAFF

P. C. Weaver

\section{FIELD STAFF}

E. N. Bailey

E. Montalvo

\section{LABORATORY STAFF}

R. D. Condra

J. S. Cox

W. P. Ivey

W. F. Smith

\section{CLERICAL STAFF}

R. M. Fink

K. M. Moore

A. Ramsey

\section{ILLUSTRATORS}

J. A. Viars 


\section{TABLE OF CONTENTS}

$\underline{\text { PAGE }}$

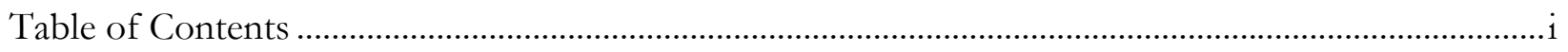

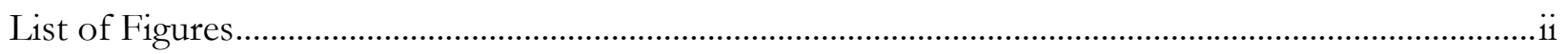

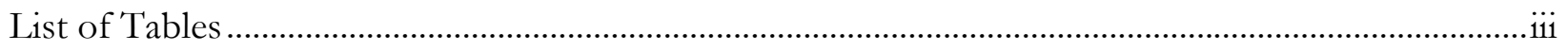

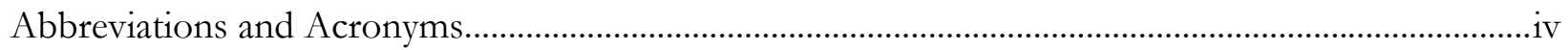

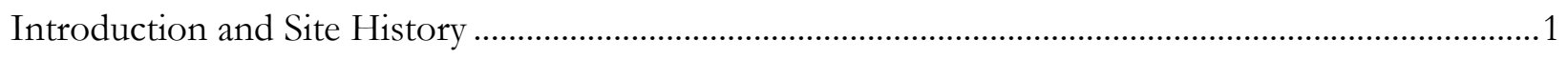

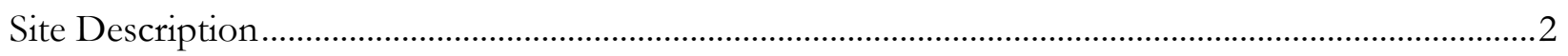

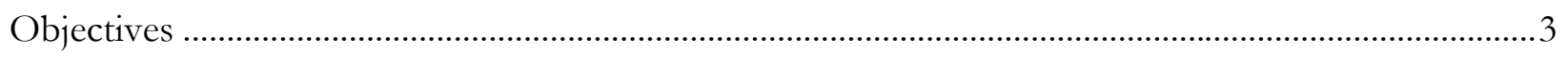

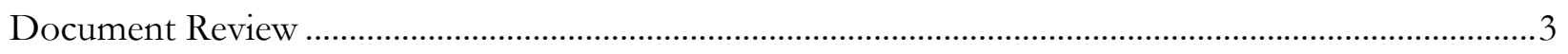

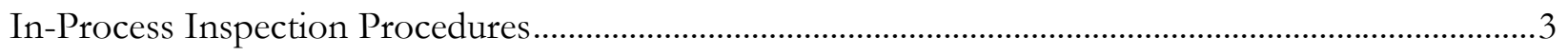

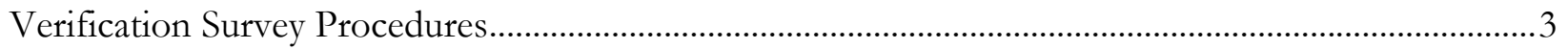

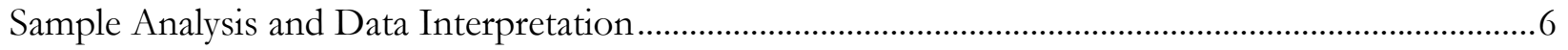

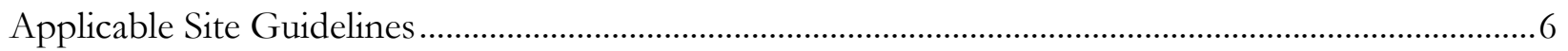

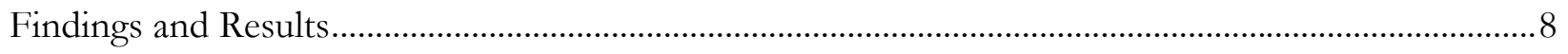

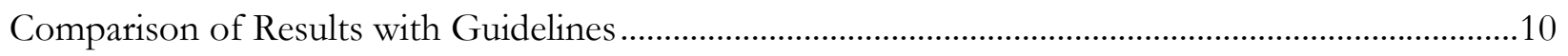

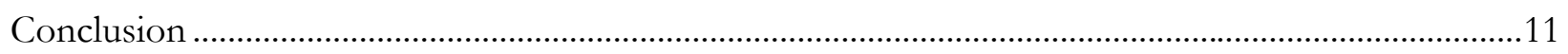

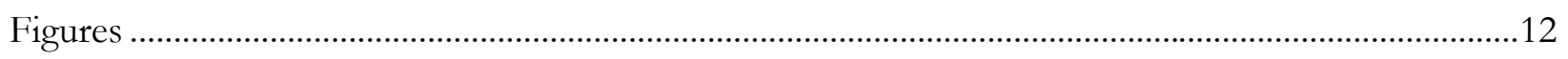

Tables

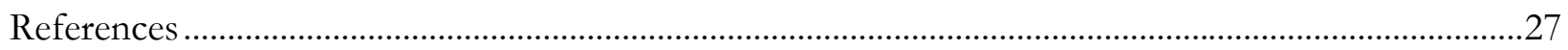

Appendices:

Appendix A: Major Instrumentation

Appendix B: Survey and Analytical Procedures

Appendix C: Data Qualifiers for Chemical Results

Appendix D: Statistical Survey Design for the OU-1 Landfill 


\section{LIST OF FIGURES}

$\underline{\text { PAGE }}$

FIGURE 1: $\quad$ Map of Miamisburg, Ohio Area - Miamisburg Closure Project ...................................13

FIGURE 2: $\quad$ Mound Closure Project Operable Unit 1 Landfill Area Plot Plan ................................14

FIGURE 3: OU-1 Landfill Survey Units ..........................................................................................

FIGURE 4: $\quad$ OU-1 Landfill Sodium Iodide Gamma Walkover Scans ................................................16

FIGURE 5: OU-1 Landfill FIDLER Walkover Scans....................................................................17

FIGURE 6: OU-1 Landfill Survey Unit 5 Chemical and Radiological Sample Locations ...............18

FIGURE 7: OU-1 Landfill Survey Unit 6 Radiological and Volatile Organic Compound Sample Locations.................................................................................................... 19

FIGURE 8: OU-1 Landfill Comparison Sample Locations..............................................................20 


\section{LIST OF TABLES}

PAGE

TABLE 1: $\quad$ Applicable Radiological Soil Guidelines...........................................................................

TABLE 2: $\quad$ Applicable Chemical Soil Guidelines ................................................................................

TABLE 3: Radionuclide Concentrations in Systematic Soil Samples OU-1 Landfill Area

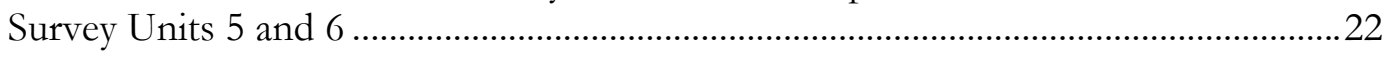

TABLE 4: Radionuclide Concentrations in Comparison Soil Samples OU-1 Landfill Area .......24

TABLE 5: $\quad$ Chemical Concentrations in Soil OU-1 Landfill............................................................ 25 


\section{ABBREVIATIONS AND ACRONYMS}

\begin{tabular}{|c|c|}
\hline$b_{i}$ & number of background counts in the interval \\
\hline & 1ndex of sensitivity \\
\hline$\mu g$ & \\
\hline$\mu \mathrm{R} / \mathrm{h}$ & microroentgens per hour \\
\hline$\mu \mathrm{rem} / \mathrm{h}$ & microrem per hour \\
\hline Am-241 & americium-241 \\
\hline $\mathrm{ARC}$ & Accelerated Remediation Corporation \\
\hline $\mathrm{BKG}$ & background \\
\hline BWXTO & Babcock and Wilcox Technical Services of Ohio \\
\hline CERCLA & $\begin{array}{l}\text { Comprehensive Environmental Response, Compensation, } \\
\text { and Liability Act }\end{array}$ \\
\hline $\mathrm{cm}$ & centimeter \\
\hline $\mathrm{cm}^{2}$ & square centimeter \\
\hline $\mathrm{CO}$ & cleanup objectives \\
\hline cpm & counts per minute \\
\hline $\mathrm{COC}$ & contaminants of concern \\
\hline DOE & U.S. Department of Energy \\
\hline $\mathrm{D} \& \mathrm{D}$ & Decontamination and Decommissioning \\
\hline EPA & Environmental Protection Agency \\
\hline FIDLER & Field Instrument for the Detection of Low Energy Radiation \\
\hline FSS & final status survey \\
\hline FSSR & final status survey report \\
\hline$g$ & gram \\
\hline GPS & global positioning system \\
\hline HS & hot spot \\
\hline ISM & Integrated Safety Management \\
\hline ITP & Intercomparison Testing Program \\
\hline IVC & Independent Verification Contractor \\
\hline IVT & Independent Verification Team \\
\hline JHA & job hazard analysis \\
\hline $\mathrm{keV}$ & kiloelectron volts \\
\hline $\mathrm{kg}$ & kilogram \\
\hline $\mathrm{LM}$ & Legacy Management \\
\hline LVLI & Lionville Laboratory, Inc. \\
\hline & meter \\
\hline $\mathrm{mg}$ & milligram \\
\hline MAPEP & Mixed Analyte Performance Evaluation Program \\
\hline MARSSIM & Multi-Agency Radiation Survey and Site Investigation Manual \\
\hline MCP & Miamisburg Closure Project \\
\hline $\mathrm{MDC}$ & minimum detectable concentration \\
\hline MDCR & minimum detectable count rate \\
\hline MERP & Mound Environmental Restoration Program \\
\hline $\mathrm{MeV}$ & million electron volts \\
\hline $\mathrm{m}^{2}$ & square meter \\
\hline $\min$ & minute \\
\hline
\end{tabular}




\section{ABBREVIATIONS AND ACRONYMS (continued)}

\begin{tabular}{|c|c|}
\hline $\mathrm{mm}$ & millimeter \\
\hline MMCIC & Miamisburg Mound Community Improvement Corporation \\
\hline MRC & Monsanto Research Corporation \\
\hline mrem & millirem \\
\hline $\mathrm{NaI}$ & sodium iodide \\
\hline NIST & National Institute of Standards and Technology \\
\hline NPL & National Priorities List \\
\hline NRIP & NIST Radiochemistry Intercomparison Program \\
\hline OEPA & Ohio Environmental Protection Agency \\
\hline ORAU & Oak Ridge Associated Universities \\
\hline ORISE & Oak Ridge Institute for Science and Education \\
\hline OU & Operable Units \\
\hline PCB & polychlorinated biphenyls \\
\hline $\mathrm{pCi} / \mathrm{g}$ & picocuries per gram \\
\hline PCE & Tetrachlorethene \\
\hline $\mathrm{P}_{\mathrm{o}}$ & fixed threshold \\
\hline PRS & Potential Release Site \\
\hline PSUD & post-excavation survey unit design \\
\hline PSP & project-specific plan \\
\hline Pu-238/239 & Plutonium 238/239 \\
\hline $\mathrm{RA}$ & Removal Action \\
\hline Ra-226 & Radium-226 \\
\hline sec & second \\
\hline SU & survey unit \\
\hline Th-230/232 & Thorium-230/232 \\
\hline TAP & total absorption peak \\
\hline TCE & Trichloroethene \\
\hline TIC & tentatively identified compounds \\
\hline VOC & volatile organic compounds \\
\hline VSAP & Verification Sampling and Analysis Plan \\
\hline VSP & Visual Sampling Plan \\
\hline yr & year \\
\hline $\mathrm{yd}^{3}$ & cubic yard \\
\hline
\end{tabular}




\section{INDEPENDENT VERIFICATION SURVEY REPORT FOR THE OPERABLE UNIT-1 LANDFILL MIAMISBURG CLOSURE PROJECT MIAMISBURG, OHIO}

\section{INTRODUCTION AND SITE HISTORY}

The Mound Plant was constructed in the 1940s for the production of nuclear weapons components. The original site was run by the Monsanto Research Corporation (MRC) whose primary mission was to determine the chemical and metallurgical properties of polonium, beginning in 1948 (BWXTO 1999). In 1949, research involving other radionuclides began and over the course of its 50 years of operation, the facility produced detonators, recovered and purified tritium, and constructed plutonium heat generators for satellites. Mound was the first permanent facility in support of atomic weapons research for the U.S. Department of Energy (DOE) and, prior to 1996, it was a supplier of stable isotopes to the DOE.

In 1989 the Mound Site was placed on the National Priorities List (NPL) because of chemical contamination in the site groundwater (BWXTO 1999). The DOE, U.S .Environmental Protection Agency (EPA), and the Ohio Environmental Protection Agency (OEPA), the DOE "core team", developed a procedural framework for the remediation of the site under the Comprehensive Environmental Response, Compensation, and Liability Act (CERCLA). In an effort to improve efficiency and streamline operations a decision-making process known as the "The Mound 2000 Approach" was developed by the Mound Environmental Restoration Program (MERP). This process divided the Mound site into 19 release blocks that contained over 400 Potential Release Sites (PRSs). Eventually, the PRSs were subdivided into nine operable units (OUs) (MERP 1997). Approximately 200 of the PRSs were contaminated soil areas and the remaining PRSs were contaminated buildings (BWXTO 1999).

During the period between 1948 and 1977, an area of about four acres on the southwest portion of the Mound Plant was used as a landfill for general trash and solid and liquid laboratory wastes contaminated with radioactive and non-radioactive materials (ARC 2006 and 2007a). This area would become known as the Operable Unit (OU)-1. Various trenches were opened in OU-1 to dispose of wastes; however, not all of the trenches were used for waste disposal. Between 1977 and 1978 , an overflow pond was constructed in the upper portion of the OU-1 area that partially 
covered the historic landfill. Waste excavated during the construction of the pond was relocated to other portions of the encapsulated OU-1 Landfill. By 1976, no additional wastes were disposed of in OU-1 (ARC 2007a).

The U.S. Department of Energy-Miamisburg Closure Project Office (DOE/MCP) is responsible for oversight of the remedial action and final status survey (FSS) activities at the Miamisburg Closure Project (MCP). It is the policy of the DOE to perform independent (third party) verification of FSS activities (DOE 2006). The purpose of these independent verifications is to confirm that remedial actions have been effective in meeting established and site-specific guidelines and that the documentation accurately and adequately describes the radiological conditions at the site. The Oak Ridge Institute for Science and Education (ORISE) has been designated by the DOE as the Independent Verification Contractor (IVC) responsible for this task at the MCP and has been requested to verify the final radiological status of the cleanup activities associated with the OU-1 Landfill.

There are both chemical and radiological contaminants of concern (COC) in the OU-1 Landfill, which include polychlorinated biphenyls (PCB), volatile organic compounds (VOCs), uranium-235/238 (U-235/238) plus daughters, plutonium-238/239 (Pu-238/239), americium-241 (Am-241), radium-226 (Ra-226) plus daughters, and thorium-230/232 (Th-230/232)) (ARC 2007a).

\section{SITE DESCRIPTION}

The Mound Plant is located on 305 acres within the southern city limits of Miamisburg, Ohio and is approximately ten miles southwest of Dayton and 45 miles north of Cincinnati. The site is bounded by Mound Avenue to the north which curves to the south becoming Mound Road and the eastern boundary of the site (Figure 1). The southern boundary is formed by Benner Road with the Conrail Railroad generally forming the western boundary. To the west of the plant is the Great Miami River flowing from northeast to southwest and the plant is surrounded by residential, recreational and agricultural areas (BWXTO 1999). The OU-1 landfill occupies approximately 4 acres of land in the southwestern portion of the original Mound Plant property (Figure 2). OU-1 has been parceled into seven survey units (SUs), two of which, (SU5 and SU6) are designated with the potential for chemical contamination (PCBs and VOCs) in addition to the potential for radiological contamination SUs (Figure 3). 


\section{OBJECTIVES}

The objectives of the independent verification survey were to confirm that remedial actions have been effective in meeting established release criteria and that documentation accurately and adequately describes the current radiological and chemical conditions of the MCP site.

\section{DOCUMENT REVIEW}

The Independent Verification Team (IVT) reviewed the work plans, verification sampling plans, and supporting data and documentation. The focus of the review included the survey methodology and instrumentation detection capabilities and calibration in order to develop an applicable and appropriate project-specific plan (PSP) for radiological field surveys.

\section{IN-PROCESS INSPECTION PROCEDURES}

In-process inspections were conducted during various stages of final status survey activities. The in-process inspection was used to identify areas in the final survey project design or procedures that could potentially result in significant and unresolved issues needing resolution prior to completion of the FSS. Additionally, in-process inspections provide valuable input that might improve the final survey process or serve as quality assurance that the project goals are being met. The in-process inspection included a review of plans and procedures, survey design and application, instrumentation and analytical capabilities, quality assurance and quality control programs, and actual field observances of measurement and sampling in various combinations. This information was utilized to evaluate and compare instrument sensitivity for field scans and measurements, final survey unit design, and elevated measurement evaluation to ensure compliance with the project's data quality objectives.

\section{VERIFICATION SURVEY PROCEDURES}

On September 19 and October 24, 2007, ORISE observed the contractor perform final status survey activities which included scans, sample collection and instrument operations, and reviewed available survey documents and procedures. During the period of November 13-16, 2007, the ORISE IVT conducted radiological verification survey activities of the OU-1 radiological and 
chemical SUs (Figure 3). Verification surveys included gamma surface scans and measurements, and collecting chemical and radiological soil samples. The ORISE IVT data quality objectives for verification of OU-1 were designed to provide assurance to DOE that the contractor has met the "hot spot" (HS) cleanup objectives (CO) that were established. Of the seven SUs in OU-1, five were Class 1 radiological and two were designated as chemical units based upon the contractor's remediation findings. Gamma surface scans that identified radioactivity levels exceeding the HS CO were marked for further investigation.

The ORISE survey design approach evaluated much of the OU-1 SUs through direct surface scans. A review of the survey approach and data provided by the contractor provided inputs relative to the ORISE survey design and determination of systematic sampling locations. ORISE selected SUs 5 and 6 to perform the verification efforts. SU 5 consists of portions of SUs 1, 3, and 4, and all of SU 2. SU 6 is essentially the footprint of SU 3 (Figure 3). Based on the contractor's remediation findings and the limited resources available for field screening PCBs, ORISE selected these units for the purpose of verification. Systematic sampling locations were generated by the Visual Sampling Plan (VSP) software. The VSP software calculated a random generated start point on the systematic grid. Both chemical and radiological samples were collected at each sample location. ORISE survey design approach for soil sampling is provided in Appendix D.

Verification survey activities were performed in accordance with the IEAV Survey Procedures and Quality Program Manuals (ORISE 2007a and ORAU 2007). Data and sample media collected during ORISE verification surveys were returned to the ORISE laboratory for data interpretation and analyses. On-site survey activities performed by ORISE were conducted in accordance with the project-specific plan that was submitted to and approved by the DOE (ORISE 2007c).

\section{REFERENCE SYSTEM}

Shape files that map each individual SU were provided by the contractor. Shape files include the SU boundaries and dimensions which were then loaded into a global positioning system (GPS) for use by the IVT for tracking survey data. The shape files were used for referencing soil sampling location coordinates that had been generated using VSP software. VSP coordinates were loaded into hand-held GPS units for use in the field by the IVT. 


\section{GAMMA SURFACE SCANS}

Surface scans to identify locations of elevated gamma radiation were performed with two different types of instruments. The Field Instrument for the Detection of Low Energy Radiation (FIDLER) detector was used for the detection of low-energy gamma radiation, and the 1.25 inch by 1.50 inch sodium iodide $(\mathrm{NaI})$ scintillation detector was used for the detection of high-energy gamma radiation. Both the NaI and FIDLER detectors were coupled to ratemeters with audible output. Scans were limited or could not be performed within a grid where significant water or other conditions prohibited access. Gamma surface scans were performed over approximately $75 \%$ of accessible areas in the OU-1 (Figures 4 and 5). Detectors were held at a nominal height of $5 \mathrm{~cm}$ above the ground surface when performing scans. Locations of elevated gamma radiation detected by surface scans were marked for further investigation

\section{SOIL SAMPLING}

Surface soil samples ( 0 to $0.15 \mathrm{~m}$ ) for radiological analyses were collected from fifty pre-determined random-start/systematic sampling locations (25 locations in SU 5 and 25 locations in SU 6) generated using the VSP version 5 software. Soils for PCB analysis were collected in SU 5 only and VOC samples were collected from SU 5 and SU 6. Both radiological and chemical samples were obtained at the same sampling location (Figures 6 and 7). Sampling locations were referenced using a GPS.

Scans by ORISE and the contractor identified at least three locations for the purpose of judgmental sampling (Figure 8). However, the contractor collected samples from two of these locations after being notified of the ORISE finding. The contractor collected both pre- and post-remediation samples. A post-remediation sample was collected to ensure that the radionuclide concentrations at the judgmental locations were below the site COs (Figure 8).

ORISE requested and received six judgmental samples (included both pre- and post-remediation samples) that were collected by the contractor for comparison of gamma spectroscopy results. These samples were evaluated to validate the quality of the contractor data in addition to quantifying radiological concentrations. 


\section{SAMPLE ANALYSIS AND DATA INTERPRETATION}

Soil samples were maintained in accordance with formal chain-of-custody procedures. Samples designated for radiological analyses were returned to the ORISE laboratory in Oak Ridge, Tennessee. Samples collected to determine PCB and VOC concentrations were analyzed by Lionville Laboratory, Inc. (LVLI) in Exton, Pennsylvania, a DOE Sample Management Office approved facility. Radiological analyses were performed in accordance with the ORISE Laboratory Procedures Manual (ORISE 2007d). Radiological soil samples were analyzed by gamma spectroscopy for all identifiable photopeaks, and alpha spectroscopy was performed to determine Am-241, Pu-238, and Pu-239 concentrations. Prior to gamma spectroscopy analysis, samples were dried and homogenized. A small aliquot of the sample was removed for alpha spectroscopy. The results were reported in units of picocuries per gram $(\mathrm{pCi} / \mathrm{g})$. Additional information concerning major instrumentation, sampling equipment, and analytical procedures is provided in Appendices A and B.

Soil samples collected for PCB and VOC analyses were analyzed at LVLI in accordance with EPA approved standard operating procedures based on SW846 method 8260B for VOCs and method 3540C based on method 8082 extracts for the isomers of PCB (EPA 2007). The results were reported in units of micrograms per kilogram $(\mu \mathrm{g} / \mathrm{kg})$ and converted to units of milligrams per kilogram $(\mathrm{mg} / \mathrm{kg})$. The data qualifiers associated with the sample results are listed in Appendix C. Data were compared with the approved release criteria established for the MCP site.

\section{APPLICABLE SITE GUIDELINES}

The applicable cleanup objectives for the primary radiological contaminants are provided in Table 1. Applicable guidelines for the primary chemical contaminants of concern are provided in Table 2. Because the contaminants were not homogenous throughout the OU-1, the COCs for any particular SU were variable. 
TABLE 1:

APPLICABLE RADIOLOGICAL SOIL GUIDELINES1

\begin{tabular}{|c|c|}
\hline Radionuclide & $\begin{array}{c}\text { Cleanup Objectives (pCi/g) } \\
\text { (average over } \mathbf{~} \mathbf{~ m}^{\mathbf{2}} \text { ) }\end{array}$ \\
\hline \hline $\mathrm{U}-235$ & 3.2 \\
\hline $\mathrm{U}-238$ & 2.2 \\
\hline $\mathrm{U}-234$ & 2.0 \\
\hline $\mathrm{Bi}-210 \mathrm{~m}$ & 8.3 \\
\hline $\mathrm{Pu}-238$ & 55 \\
\hline $\mathrm{Pu}-239 / 240$ & 62 \\
\hline $\mathrm{Am}-241$ & 63 \\
\hline $\mathrm{Ra}-226+\mathrm{Daughters}$ & 2.9 \\
\hline $\mathrm{Ac}-227$ & 4.6 \\
\hline $\mathrm{Pa}-231$ & 4.0 \\
\hline $\mathrm{Pb}-210$ & 7.4 \\
\hline Th-230 & 2.8 \\
\hline Th-232 & 2.1 \\
\hline
\end{tabular}

${ }^{1}$ ARC 2007: Soils Verification Sampling and Analysis Plan Mound Operable Unit 1 Landfill Area Appendix E Table 1.

TABLE 2:

APPLICABLE CHEMICAL SOIL GUIDELINES ${ }^{1}$

\begin{tabular}{|c|c|}
\hline Analyte & $\begin{array}{c}\text { Guideline Limits } \mathbf{( m g} / \mathbf{k g}) \\
\text { (average over } \mathbf{~} \mathbf{~}^{\mathbf{2}} \text { ) }\end{array}$ \\
\hline \hline Tetrachlorethene & $1.87 \mathrm{E}+02$ \\
\hline Trichloroethene & $5.25 \mathrm{E}+01$ \\
\hline Vinyl Chloride & $4.14 \mathrm{E}+00$ \\
\hline Chloroform & $5.15 \mathrm{E}+00$ \\
\hline Ethylbenzene & $4.8 \mathrm{E}-01$ \\
\hline Toluene & $2.50 \mathrm{E}+02$ \\
\hline PCB (total) & $4.26 \mathrm{E}+00$ \\
\hline
\end{tabular}

${ }^{1}$ ARC 2007: Partial 1, Post-Excavation Survey Unit Design Survey Design Survey Units 1, 2, 3, 4, 5, and 6 Only OU-1 Landfill Project, Miamisburg, OH. Addendums 5 and 6 (ARC 2007). 


\section{FINDINGS AND RESULTS}

\section{DOCUMENT REVIEW}

ORISE provided technical review and comments on the verification sampling and analysis plan (VSAP) for the Mound Operable Unit 1 Landfill area (ORISE 2007b). Additionally, ORISE reviewed the draft post-excavation survey unit design (PSUD) and survey procedures to determine if the goals as stated in the VSAP were being effectively implemented. Generally, the VSAP for the Mound OU-1 Landfill area followed the requirements specified in the Mound 2000 Approach (BWXTO 1999) and the response action plan for the OU-1 Landfill area (ARC 2006). However, several technical issues were identified during the review of the VSAP and supporting procedures which were quickly addressed by the contractor (ARC 2007b and ORISE 2007b). ORISE conducted two visits to the site for information gathering and observation, and to perform an in-process inspection of the various survey activities conducted by the contractor. The ORISE protocol for in-process inspections consisted of a series of questions to evaluate the overall effectiveness of the contractor's survey program in meeting the approved site COs. Three items from the list were recommended for review and improvement. The first recommendation was the clarification as to how the contractor would meet the approved COs-e.g., use of surrogate measurements and modified CO, comparison of results with maximum $\mathrm{CO}$, or implementation of the unity rule (as applicable). ORISE recommended application of the unity rule when comparing the analytical results to the $\mathrm{CO}$. The second recommendation was to adjust the range scale for the FIDLER detector during scanning in addition to using the audio capability for quickly discerning a change in radioactivity levels. The third recommendation was to follow the procedure requirement for the removal of excess water from a soil sample (ORISE 2007e). The contractor quickly addressed these issues (DOE 2007).

\section{GAMMA SCANS}

The gross (including background) area ambient gamma radiation scan results for the $\mathrm{NaI}$ detector were generally between 2500 to $4800 \mathrm{cpm}$ with an average of $3500 \mathrm{cpm}$. A review of the collected data indicated that four locations at or slightly greater than $6000 \mathrm{cpm}$ were identified during the NaI scans (Figure 4). FIDLER scan results were generally between 150 to $400 \mathrm{cpm}$ and averaged around $245 \mathrm{cpm}$. Scans using the FIDLER detector identified two small distinct isolated locations of 
elevated radioactivity (Figure 5). The highest level of activity exceeded $6500 \mathrm{cpm}$. ORISE notified the contractor of the findings.

\section{SOIL SAMPLING}

\section{Radionuclide Concentrations in Soil}

The results of radionuclide concentrations, as determined by gamma spectrometry, for random-start/systematic soil samples are reported in Table 3. Alpha spectroscopy analysis was performed for two batches of selected samples from SU 5 and SU-6 to evaluate Pu-238 and Pu-239 concentrations. All random-start/systematic soil samples results were below the COs established for the site.

The radionuclide concentrations of samples obtained from the contractor for data validation have been provided in Table 4. These samples were analyzed by both alpha and gamma spectroscopy. Am-241, Pu-239, Th-230, Th-232, and U-238 were the predominant COCs that were identified for the SUs. In the pre-remediation sample 051, the Th-232 concentration exceeded the HS criteria having a concentration of $20.6 \mathrm{pCi} / \mathrm{g}$ and the $\mathrm{U}-238$ concentration of $4.3 \mathrm{pCi} / \mathrm{g}$ exceeded the $\mathrm{CO}$; however, this is less than the HS criteria. Sample 052 was collected as a post- remediation sample to 051 and the concentrations were well below the COs. The CO for Am-241 was exceeded in sample 053 (82.6 pCi/g); however, this was much less than the HS criteria. The Pu-239 concentration in sample 054, as determined by alpha spectrometry, was $790 \mathrm{pCi} / \mathrm{g}$. Sample 055 was a follow-up to sample 054 , to ensure that residual contamination had been sufficiently removed such that the soil levels would meet the CO.

\section{Chemical Concentrations in Soil}

The results of chemical analyses for VOCs and PCBs in soil concentrations are provided in Table 5. PCB samples were collected only from SU 5 based on contractor results and site history. PCB concentrations ranged from 0.0067 to $25 \mathrm{mg} / \mathrm{kg}$. Samples PCB001, PCB006, PCB011, and PCB016 did exceed the CO for PCBs established for the site. Vinyl Chloride concentrations ranged from 0.008 to $0.015 \mathrm{mg} / \mathrm{kg}$, Chloroform from 0.001 to $0.015 \mathrm{mg} / \mathrm{kg}$, TCE from 0.0009 to $1.4 \mathrm{mg} / \mathrm{kg}$, 
PCE from 0.001 to $4.2 \mathrm{mg} / \mathrm{kg}$, Toluene from 0.0008 to $0.013 \mathrm{mg} / \mathrm{kg}$, and Ethylbenzene from 0.001 to $0.008 \mathrm{mg} / \mathrm{kg}$. All concentrations were well below the COs for the site.

\section{COMPARISON OF RESULTS WITH GUIDELINES}

\section{Radionuclide Concentrations}

The radionuclide concentrations in random-start/systematic soil samples collected from the various SUs evaluated by the IVT were below the CO for the listed site COCs, including the samples analyzed for Pu-238 and Pu-239 by alpha spectroscopy. The six soil samples obtained by the IVT from the contractor for interlaboratory comparison were analyzed by the contractor using a qualitative field screen method and were not sent off-site for laboratory analysis. Therefore, a direct comparison of the IVT and contractor results could not be performed. However, the IVT was able to validate that the contractor field screening method was sensitive enough to confirm that the COCs were less than the CO. Three (051, 053, and 054) of these samples did exceed the COs for Th-232, Am-241, and Pu-239, respectively. However, these samples represented small discrete pockets of contamination and no additional remediation was required with the exception of sample location 051 where a very small quantity of soil was removed.

\section{Chemical Concentrations}

PCB concentrations in four samples collected from SU 5 (PCB001, PCB006, PCB011, and PCB016) exceeded the site CO, of which two exceeded the HS CO (Table 5). To adequately determine that there was not a uniform failure of remedial actions in the SU, the Sign Test statistic was performed; meaning that the null hypothesis assumes that the average PCB concentration in the SU to be greater than the CO. For the Sign Test, a critical value of 17 was determined, using Table I-3, Appendix I of the Multi-Agency Radiation Survey and Site Investigation Manual (MARSSIM), based on having 25 samples (n) and an alpha error of 0.05 (NRC 2000). The average total PCB

concentration for SU 5 was $3.58 \mathrm{mg} / \mathrm{kg}$ and standard deviation of 6.16 . The median was $1.7 \mathrm{mg} / \mathrm{kg}$. The number of positive differences, as determine by the Sign Test, was 21 exceeding the critical value; thereby rejecting the null hypothesis. The results for VOCs in SU 5 and SU 6 were all below the site CO's. 


\section{CONCLUSION}

On September 19 and October 24, 2007, ORISE observed final status surveys performed by the contractor including, instrument operations and document review at the MCP. The in-process inspection and document review identified a few technical issues that were subsequently addressed by the contractor (ARC 2007b and ORISE 2007b and 2007e).

During the period from November 13-16, 2007, the ORISE IVT conducted independent verification survey activities at the 4 acre OU-1 landfill. The IV included gamma scans and soil sampling for radiological and chemical COCs. Low energy gamma radiation scans performed by the IVT identified two very small isolated locations that were sampled and field screened by the contractor. The IVT requested the samples from these two locations as well as an additional sampling location, where elevated radioactivity was identified, to validate the contractor field screening results. A qualitative comparison of the ORISE results and the contractor results indicates that the contractors field screening method has the detection sensitivity necessary to evaluate COC concentrations.

Chemical sampling conducted by ORISE identified PCB concentrations in four samples exceeding the site CO of which two exceeded the hot spot (HS) criteria. These two samples were located in the same area where the contractor also identified PCB levels exceeding the CO. Additional remediation was performed to remove additional waste material (DNS 2007). No VOCs were found in excess of the $\mathrm{CO}$. Based on the results of independent verification activities performed by ORISE at the MCP, ORISE's concludes that the evaluated areas satisfy the applicable site cleanup objectives. 


\section{FIGURES}




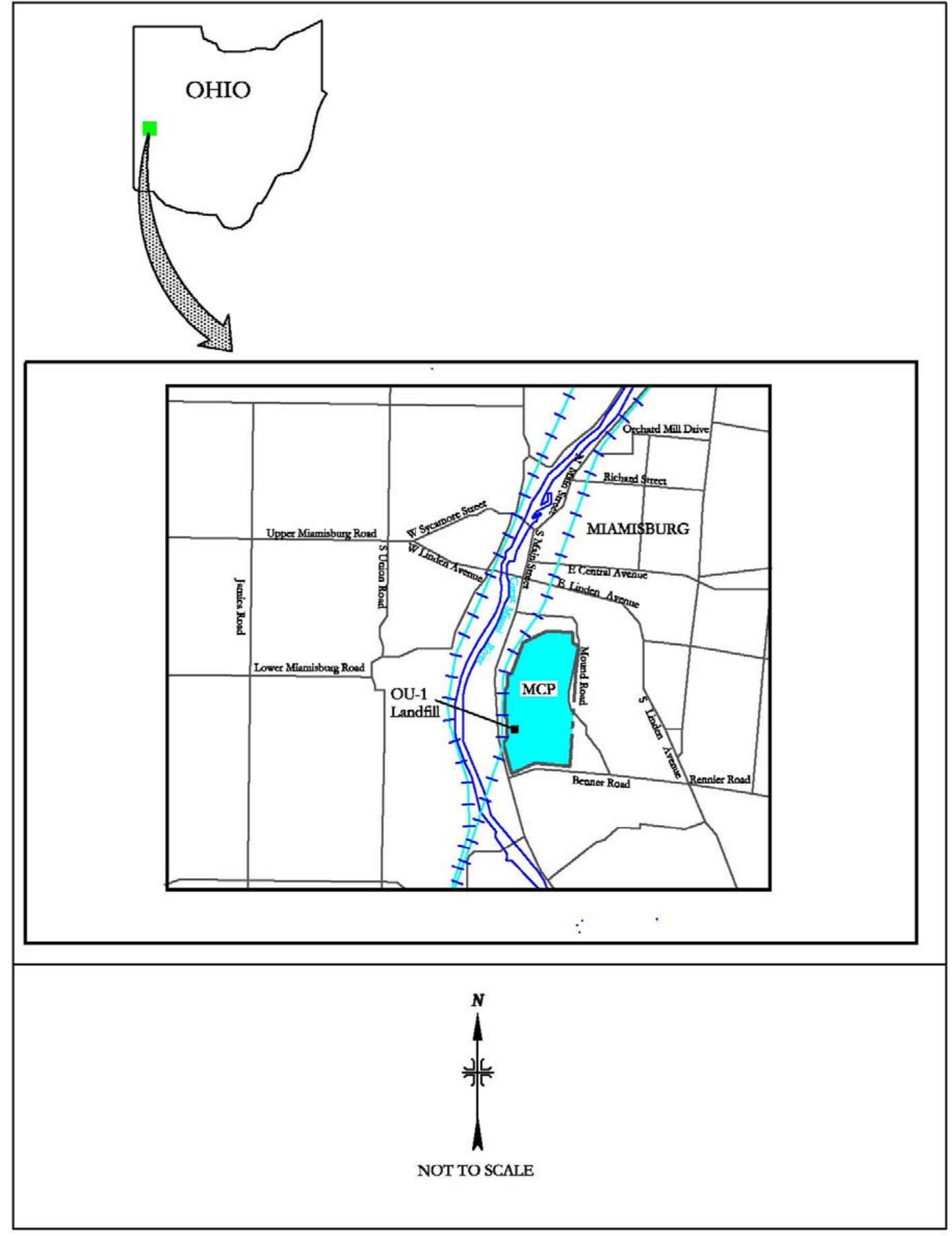

Figure 1: Map of Miamisburg, Ohio Area - Miamisburg Closure Project 


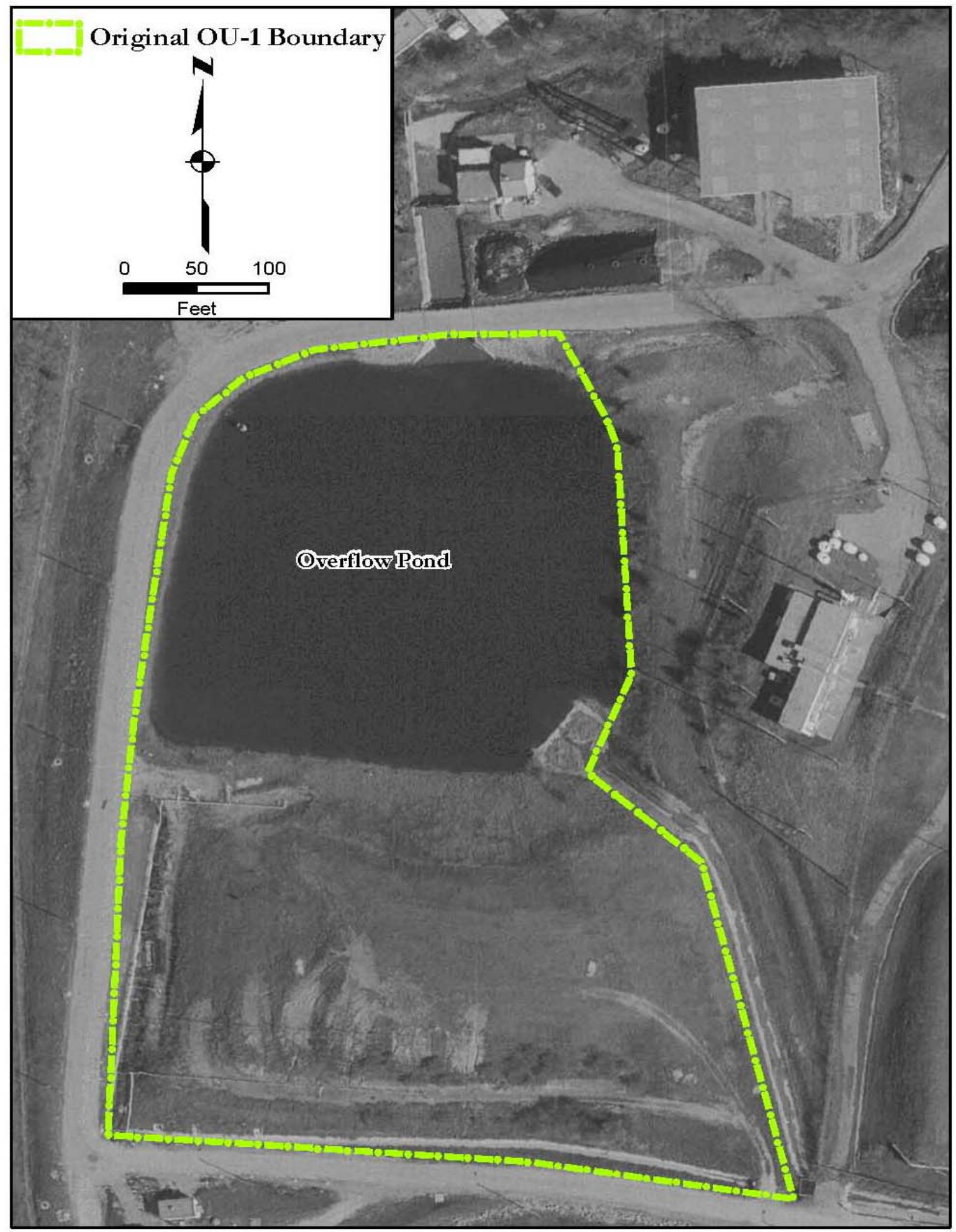

Figure 2: Miamisburg Closure Project Operable Unit 1 Landfill Area Plot Plan 


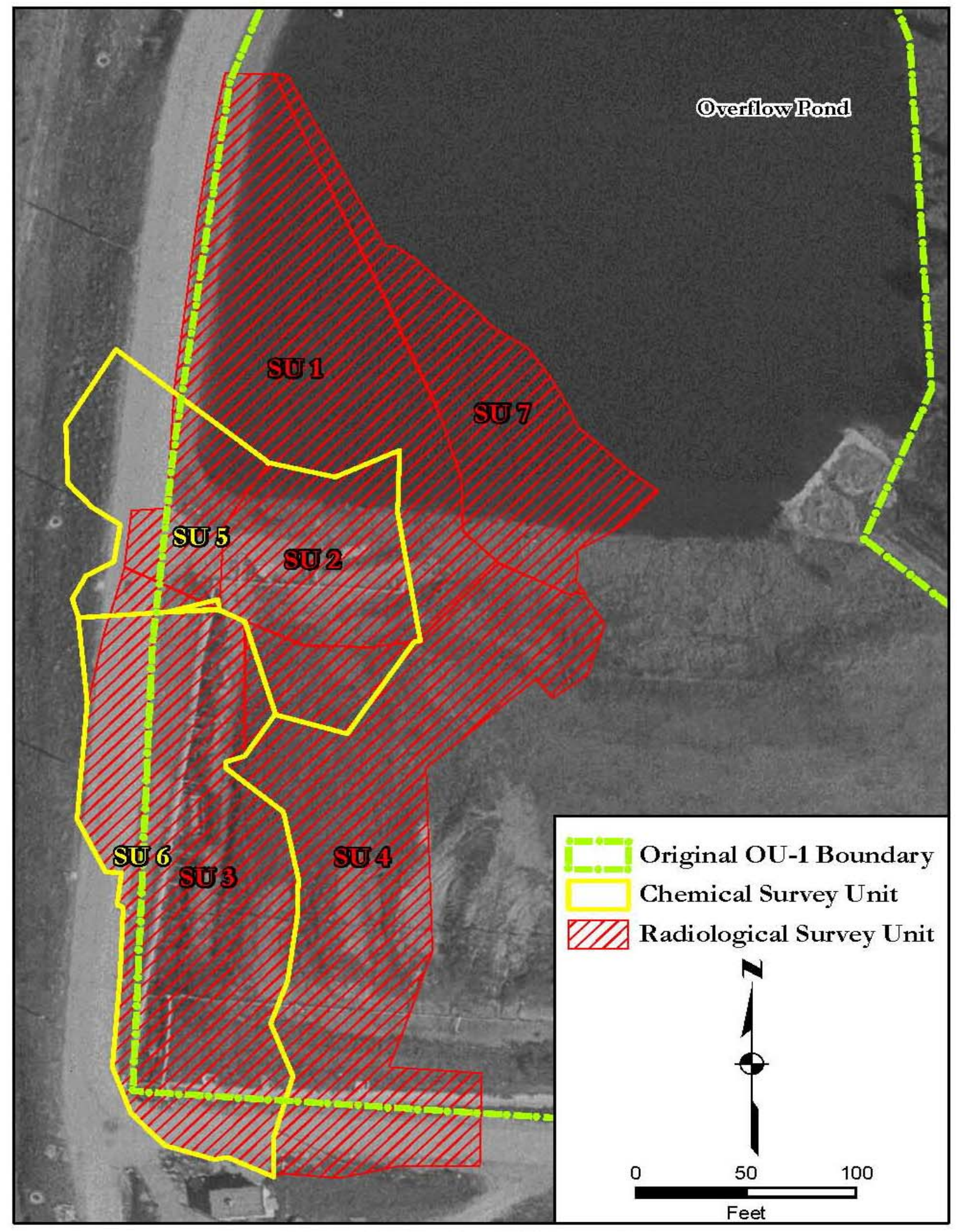

Figure 3: OU-1 Landfill Survey Units 


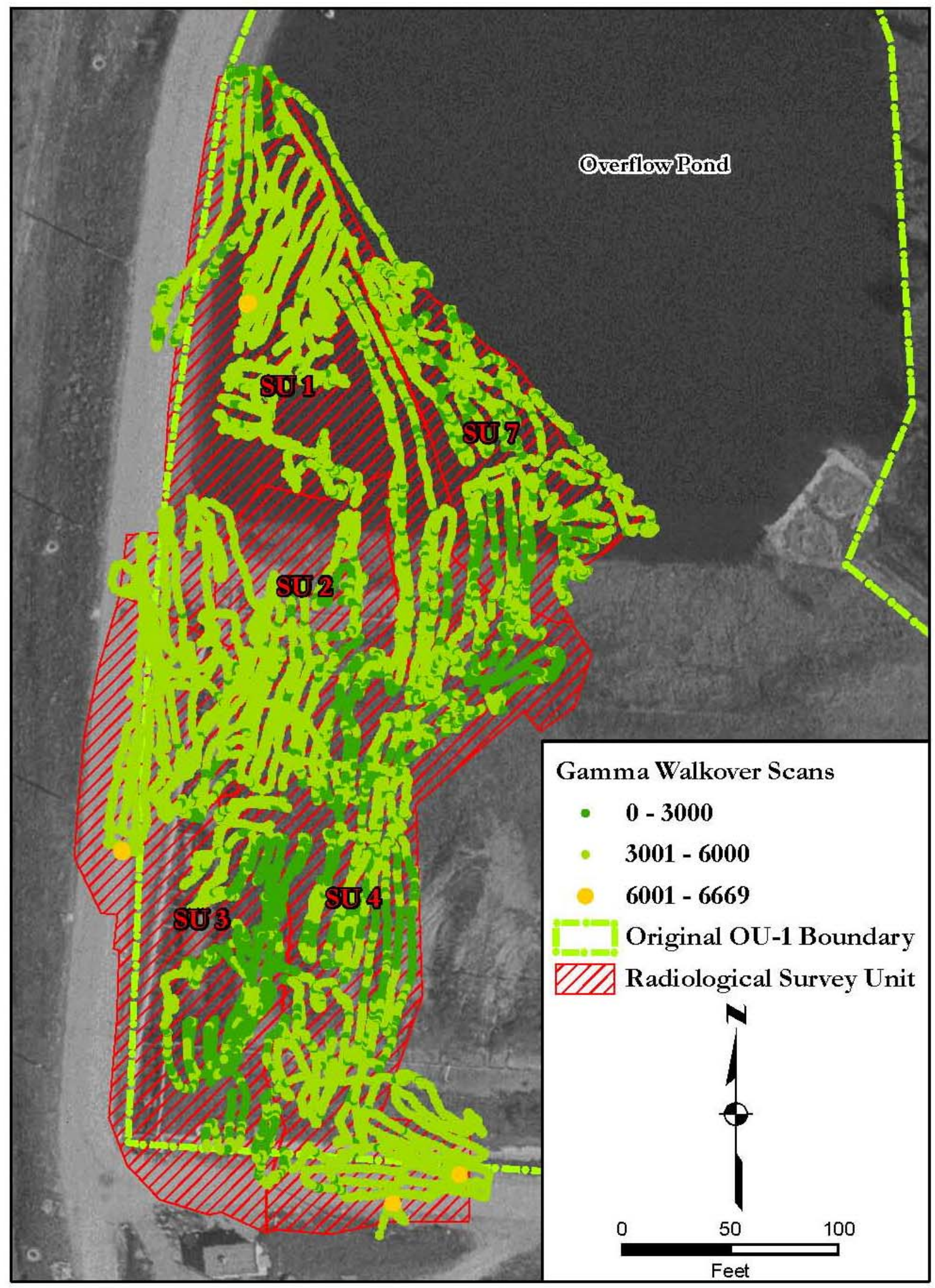

Figure 4: OU-1 Landfill Sodium Iodide Gamma Walkover Scans 


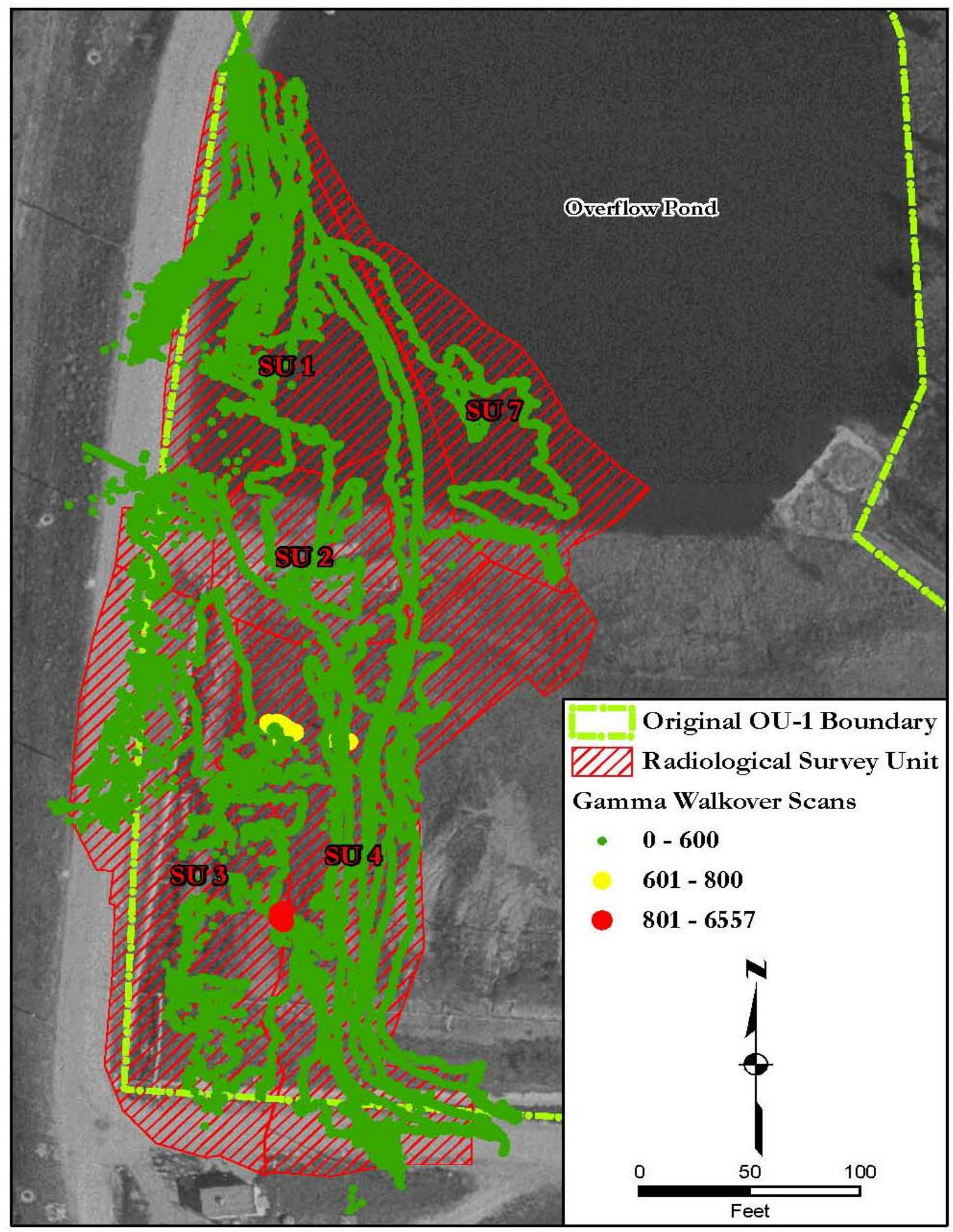

Figure 5: OU-1 Landfill FIDLER Walkover Scans 


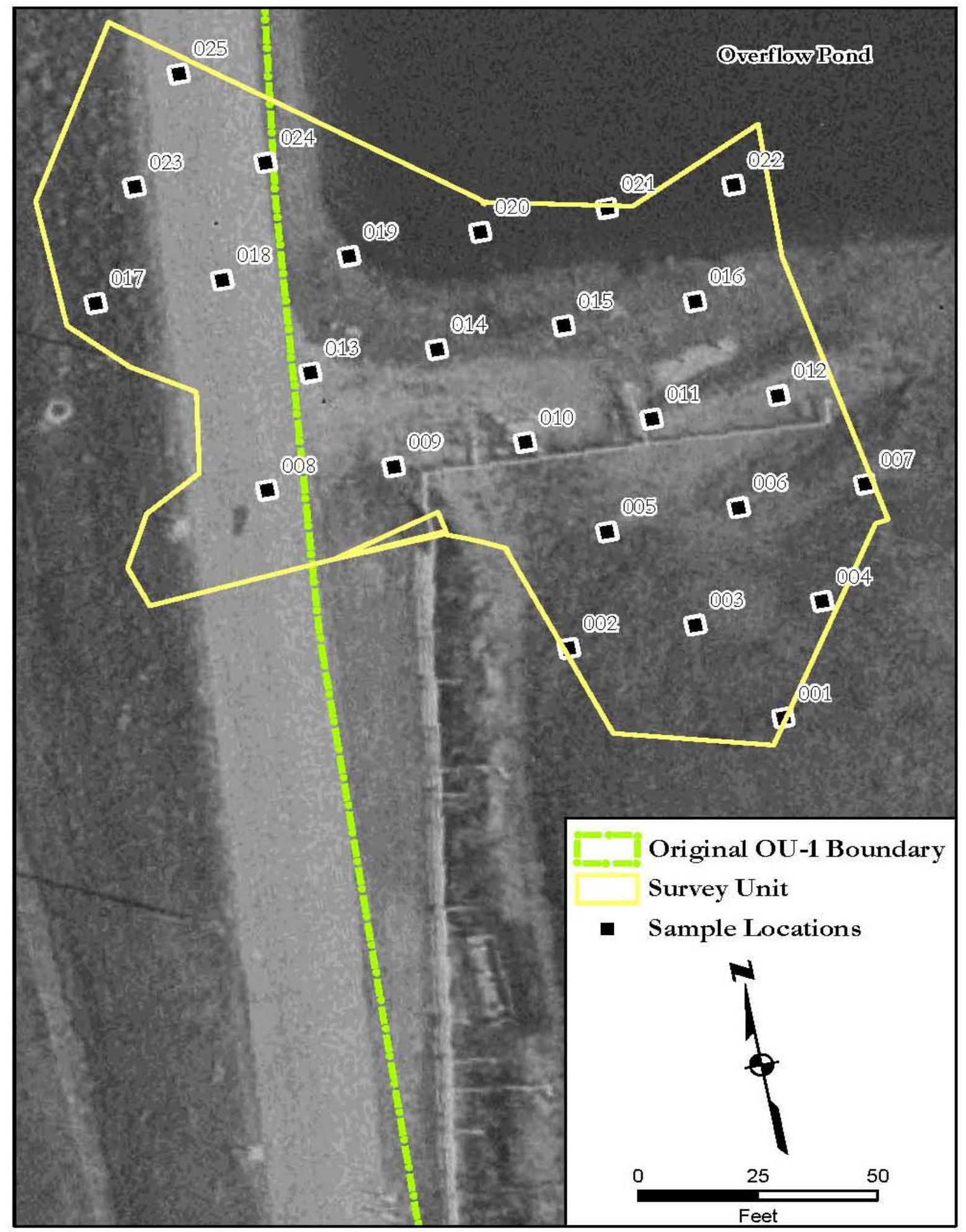

Figure 6: OU-1 Landfill Survey Unit 5 Chemical and Radiological Sampler Locations 


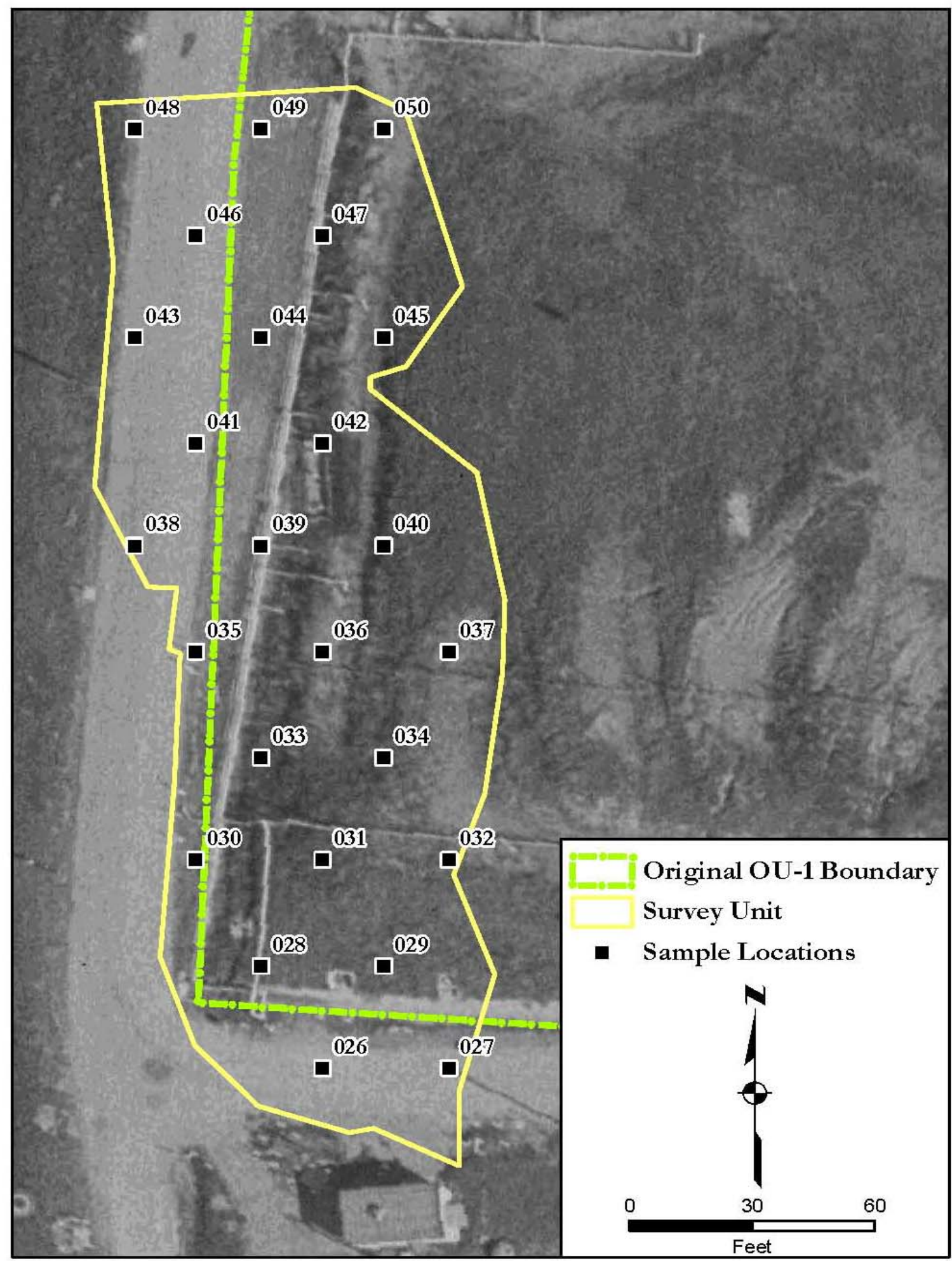

Figure 7: OU-1 Landfill Survey Unit 6 Radiological and Volatile Organic Compound Sample Locations 


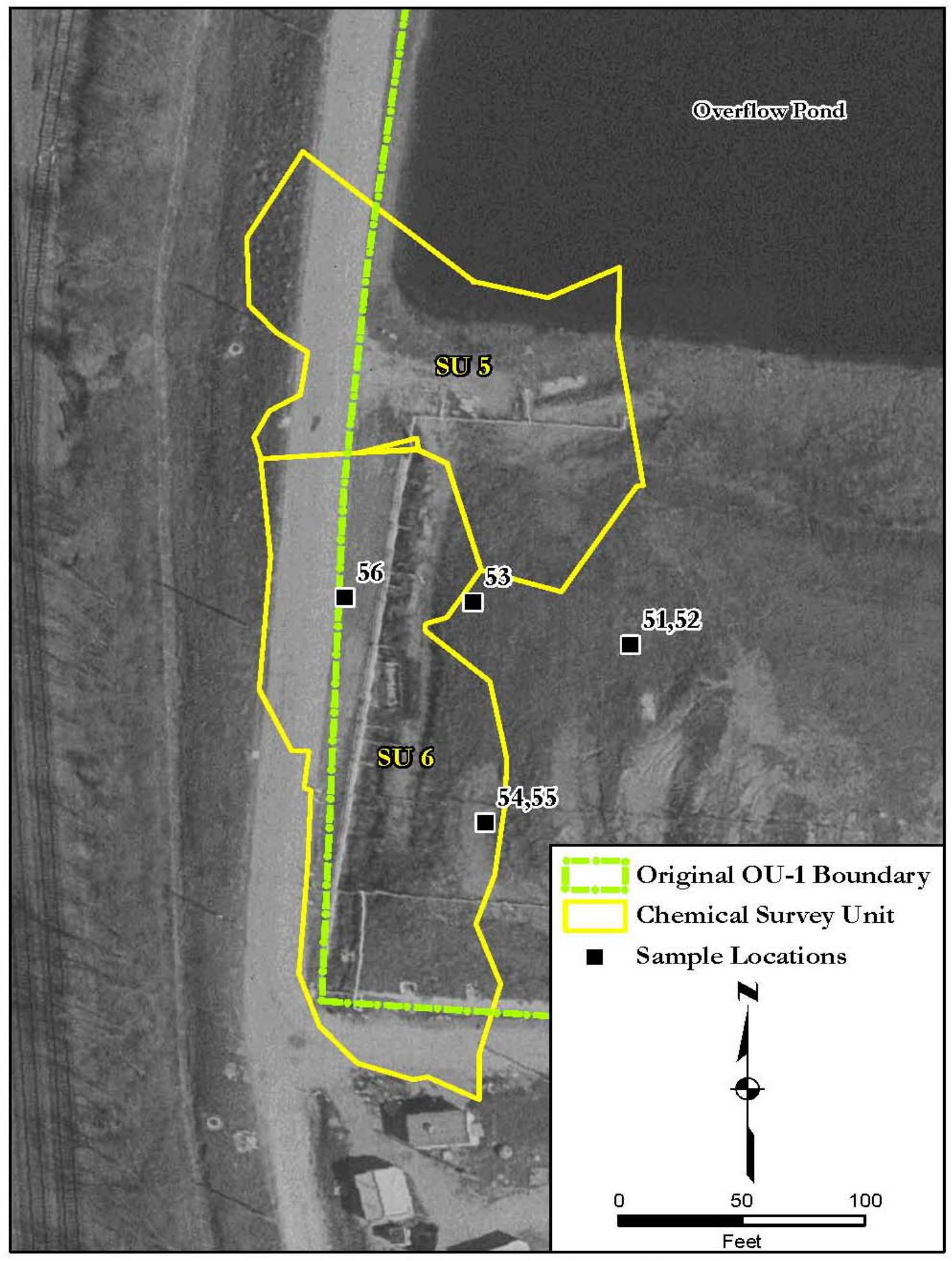

Figure 8: OU-1 Landfill Comparison Sample Locations 


\section{TABLES}


TABLE 3

RADIONUCLIDE CONCENTRATIONS IN SYSTEMATIC SOIL SAMPLES

OU-1 LANDFILL AREA

SURVEY UNITS 5 AND 6

MOUND CLOSURE PROJECT

MIAMISBURG, OHIO

\begin{tabular}{l|l} 
ORISE $^{a}$ & Radionuclide Concentrations in Soil Samples (pCi/g)
\end{tabular}

\begin{tabular}{|c|c|c|c|c|c|c|c|c|c|c|c|}
\hline \multirow{2}{*}{$\begin{array}{l}\text { ORISE }^{\mathrm{a}} \\
\text { Sample ID }\end{array}$} & \\
\hline & $\mathrm{Pu}-238^{\mathrm{b}}$ & $\mathrm{Pu}-239^{\mathrm{b}}$ & $\mathrm{Am}-241^{\mathrm{c}}$ & Th-230 & Ra-226 & Th-232 & U-238 & U-235 & $\mathrm{Pb}-210$ & $\mathrm{~Pa}-231$ & Ac-227 \\
\hline \multicolumn{12}{|c|}{ Survey Unit 5} \\
\hline $0468 S 0001$ & $--\mathrm{d}$ & --- & $0.01 \pm 0.03^{\mathrm{e}}$ & $-0.7 \pm 3.0$ & $0.78 \pm 0.08$ & $0.66 \pm 0.13$ & $1.18 \pm 0.49$ & $0.09 \pm 0.10$ & $1.20 \pm 0.45$ & $0.07 \pm 0.52$ & $0.19 \pm 0.15$ \\
\hline $0468 \mathrm{~S} 0002$ & $0.16 \pm 0.04$ & $0.01 \pm 0.01$ & $0.00 \pm 0.04$ & $3.0 \pm 3.0$ & $1.21 \pm 0.10$ & $0.72 \pm 0.18$ & $1.20 \pm 0.52$ & $0.07 \pm 0.10$ & $1.66 \pm 0.49$ & $-0.16 \pm 0.77$ & $0.00 \pm 0.18$ \\
\hline $0468 \mathrm{~S} 0003$ & $0.19 \pm 0.05$ & $0.01 \pm 0.01$ & $0.04 \pm 0.04$ & $4.2 \pm 4.7$ & $0.91 \pm 0.08$ & $0.49 \pm 0.14$ & $0.62 \pm 0.40$ & $0.13 \pm 0.11$ & $1.10 \pm 0.51$ & $0.03 \pm 0.65$ & $-0.01 \pm 0.15$ \\
\hline $0468 S 0004$ & --- & --- & $0.01 \pm 0.04$ & $1.8 \pm 4.6$ & $0.76 \pm 0.08$ & $0.64 \pm 0.17$ & $0.86 \pm 0.52$ & $-0.01 \pm 0.10$ & $1.26 \pm 0.42$ & $0.24 \pm 0.67$ & $0.04 \pm 0.17$ \\
\hline $0468 \mathrm{~S} 0005$ & --- & --- & $0.03 \pm 0.04$ & $5.2 \pm 3.7$ & $0.83 \pm 0.09$ & $0.51 \pm 0.17$ & $1.04 \pm 0.48$ & $0.13 \pm 0.10$ & $0.84 \pm 0.52$ & $-0.32 \pm 0.62$ & $-0.05 \pm 0.16$ \\
\hline $0468 \mathrm{~S} 0006$ & $3.96 \pm 0.34$ & $0.07 \pm 0.02$ & $0.04 \pm 0.04$ & $0.0 \pm 3.0$ & $0.88 \pm 0.07$ & $0.66 \pm 0.12$ & $1.26 \pm 0.37$ & $0.10 \pm 0.10$ & $1.04 \pm 0.45$ & $-0.24 \pm 0.61$ & $0.06 \pm 0.15$ \\
\hline $0468 \mathrm{~S} 0007$ & --- & --- & $0.04 \pm 0.04$ & $3.0 \pm 3.4$ & $0.89 \pm 0.08$ & $0.76 \pm 0.13$ & $0.99 \pm 0.36$ & $0.09 \pm 0.11$ & $0.94 \pm 0.43$ & $0.05 \pm 0.71$ & $0.00 \pm 0.16$ \\
\hline $0468 \mathrm{~S} 0008$ & --- & --- & $0.02 \pm 0.05$ & $0.2 \pm 4.3$ & $1.19 \pm 0.11$ & $0.97 \pm 0.19$ & $0.63 \pm 0.65$ & $0.12 \pm 0.13$ & $1.60 \pm 0.61$ & $-0.13 \pm 0.89$ & $-0.19 \pm 0.26$ \\
\hline 0468S0009 & --- & --- & $0.02 \pm 0.03$ & $0.4 \pm 2.9$ & $0.86 \pm 0.08$ & $0.68 \pm 0.12$ & $0.91 \pm 0.44$ & $0.06 \pm 0.10$ & $1.33 \pm 0.51$ & $-0.79 \pm 0.62$ & $-0.08 \pm 0.14$ \\
\hline $0468 \mathrm{~S} 0010$ & $0.07 \pm 0.03$ & $0.01 \pm 0.01$ & $0.00 \pm 0.03$ & $0.9 \pm 3.1$ & $0.88 \pm 0.09$ & $0.57 \pm 0.15$ & $1.30 \pm 0.52$ & $0.05 \pm 0.08$ & $0.91 \pm 0.55$ & $0.17 \pm 0.65$ & $0.11 \pm 0.16$ \\
\hline $0468 \mathrm{~S} 0011$ & --- & --- & $0.04 \pm 0.05$ & $0.3 \pm 3.8$ & $0.76 \pm 0.09$ & $0.58 \pm 0.15$ & $0.95 \pm 0.45$ & $0.07 \pm 0.10$ & $0.42 \pm 0.57$ & $0.11 \pm 0.68$ & $0.09 \pm 0.17$ \\
\hline $0468 \mathrm{~S} 0012$ & --- & --- & $0.01 \pm 0.05$ & $0.0 \pm 4.3$ & $1.11 \pm 0.11$ & $0.78 \pm 0.17$ & $1.39 \pm 0.64$ & $0.17 \pm 0.14$ & $1.12 \pm 0.67$ & $0.08 \pm 0.83$ & $0.20 \pm 0.20$ \\
\hline $0468 \mathrm{~S} 0013$ & --- & --- & $0.02 \pm 0.04$ & $-3.4 \pm 3.8$ & $1.10 \pm 0.09$ & $0.91 \pm 0.17$ & $1.31 \pm 0.57$ & $0.04 \pm 0.09$ & $1.54 \pm 0.52$ & $0.25 \pm 0.63$ & $-0.03 \pm 0.18$ \\
\hline $0468 S 0014$ & --- & --- & $0.02 \pm 0.03$ & $2.9 \pm 3.5$ & $0.95 \pm 0.08$ & $0.68 \pm 0.12$ & $0.97 \pm 0.46$ & $0.09 \pm 0.09$ & $1.26 \pm 0.45$ & $0.24 \pm 0.66$ & $0.09 \pm 0.16$ \\
\hline $0468 \mathrm{~S} 0015$ & --- & --- & $0.00 \pm 0.04$ & $3.7 \pm 4.6$ & $0.82 \pm 0.08$ & $0.50 \pm 0.12$ & $0.84 \pm 0.44$ & $0.02 \pm 0.08$ & $1.19 \pm 0.61$ & $-0.65 \pm 0.63$ & $0.01 \pm 0.16$ \\
\hline $0468 \mathrm{~S} 0016$ & $\begin{array}{c}-- \\
\end{array}$ & $\begin{array}{l}--- \\
\end{array}$ & $0.03 \pm 0.05$ & $1.9 \pm 4.5$ & $0.90 \pm 0.10$ & $0.81 \pm 0.18$ & $1.06 \pm 0.67$ & $0.00 \pm 0.10$ & $0.85 \pm 0.61$ & $-0.08 \pm 0.79$ & $-0.08 \pm 0.19$ \\
\hline $0468 \mathrm{~S} 0017$ & $0.53 \pm 0.08$ & $0.02 \pm 0.01$ & $0.04 \pm 0.04$ & $-4.3 \pm 4.2$ & $0.81 \pm 0.09$ & $0.66 \pm 0.17$ & $0.98 \pm 0.53$ & $0.07 \pm 0.12$ & $1.26 \pm 0.70$ & $0.28 \pm 0.73$ & $0.07 \pm 0.20$ \\
\hline $0468 \mathrm{~S} 0018$ & --- & --- & $0.02 \pm 0.04$ & $-0.7 \pm 3.6$ & $0.90 \pm 0.09$ & $0.55 \pm 0.15$ & $1.12 \pm 0.47$ & $0.00 \pm 0.09$ & $1.30 \pm 0.61$ & $-0.29 \pm 0.65$ & $0.11 \pm 0.17$ \\
\hline $0468 \mathrm{~S} 0019$ & --- & --- & $0.00 \pm 0.03$ & $0.9 \pm 3.2$ & $1.03 \pm 0.08$ & $0.79 \pm 0.14$ & $1.12 \pm 0.49$ & $0.00 \pm 0.09$ & $1.46 \pm 0.52$ & $-0.38 \pm 0.60$ & $0.12 \pm 0.16$ \\
\hline $0468 \mathrm{~S} 0020$ & $0.16 \pm 0.04$ & $0.00 \pm 0.01$ & $-0.03 \pm 0.03$ & $1.9 \pm 2.8$ & $0.93 \pm 0.08$ & $0.54 \pm 0.14$ & $1.01 \pm 0.47$ & $0.06 \pm 0.12$ & $1.22 \pm 0.43$ & $-0.14 \pm 0.64$ & $0.16 \pm 0.22$ \\
\hline $0468 \mathrm{~S} 0021$ & --- & --- & $0.03 \pm 0.04$ & $-1.5 \pm 3.5$ & $0.88 \pm 0.09$ & $0.52 \pm 0.15$ & $1.23 \pm 0.54$ & $0.09 \pm 0.10$ & $1.43 \pm 0.58$ & $0.48 \pm 0.73$ & $-0.03 \pm 0.17$ \\
\hline $0468 \mathrm{~S} 0022$ & --- & --- & $0.05 \pm 0.04$ & $6.5 \pm 5.8$ & $1.33 \pm 0.12$ & $1.12 \pm 0.19$ & $1.48 \pm 0.63$ & $0.00 \pm 0.10$ & $1.82 \pm 0.59$ & $-0.38 \pm 0.86$ & $-0.10 \pm 0.21$ \\
\hline $0468 \mathrm{~S} 0023$ & $0.02 \pm 0.02$ & $0.00 \pm 0.00$ & $0.01 \pm 0.03$ & $-0.4 \pm 2.7$ & $0.89 \pm 0.08$ & $0.57 \pm 0.14$ & $0.94 \pm 0.40$ & $0.09 \pm 0.08$ & $1.12 \pm 0.36$ & $0.57 \pm 0.60$ & $0.05 \pm 0.17$ \\
\hline $0468 \mathrm{~S} 0024$ & --- & --- & $0.04 \pm 0.03$ & $2.0 \pm 2.9$ & $1.03 \pm 0.08$ & $0.56 \pm 0.11$ & $1.27 \pm 0.54$ & $0.25 \pm 0.15$ & $1.41 \pm 0.48$ & $-0.09 \pm 0.53$ & $0.11 \pm 0.14$ \\
\hline $0468 \mathrm{~S} 0025$ & --- & --- & $0.01 \pm 0.04$ & $0.7 \pm 4.0$ & $0.95 \pm 0.09$ & $0.49 \pm 0.17$ & $0.85 \pm 0.63$ & $-0.01 \pm 0.10$ & $0.92 \pm 0.66$ & $-0.60 \pm 0.77$ & $0.11 \pm 0.19$ \\
\hline \multicolumn{12}{|c|}{ Survey Unit 6} \\
\hline $0468 \mathrm{~S} 0026$ & --- & & $0.02 \pm 0.05$ & $-0.3 \pm 4.0$ & $0.94 \pm 0.10$ & $1.03 \pm 0.19$ & $0.85 \pm 0.62$ & $0.07 \pm 0.17$ & $1.36 \pm 0.49$ & $-0.57 \pm 0.77$ & $-0.12 \pm 0.20$ \\
\hline $0468 \mathrm{~S} 0027$ & $0.01 \pm 0.02$ & $0.00 \pm 0.01$ & $0.04 \pm 0.04$ & $-0.9 \pm 4.2$ & $0.98 \pm 0.10$ & $0.68 \pm 0.14$ & $1.07 \pm 0.64$ & $0.04 \pm 0.11$ & $1.24 \pm 0.54$ & $0.30 \pm 0.67$ & $-0.01 \pm 0.18$ \\
\hline $0468 \mathrm{~S} 0028$ & --- & --- & $0.03 \pm 0.04$ & $-3.2 \pm 4.0$ & $1.08 \pm 0.09$ & $1.18 \pm 0.21$ & $1.08 \pm 0.61$ & $0.08 \pm 0.12$ & $1.37 \pm 0.63$ & $-0.19 \pm 0.73$ & $0.13 \pm 0.18$ \\
\hline
\end{tabular}


TABLE 3

RADIONUCLIDE CONCENTRATIONS IN SYSTEMATIC SOIL SAMPLES

OU-1 LANDFILL AREA

SURVEY UNITS 5 AND 6

MOUND CLOSURE PROJECT

MIAMISBURG, OHIO

(continued)

Radionuclide Concentrations in Soil Samples (pCi/g)

$0468 \mathrm{~S} 0029$

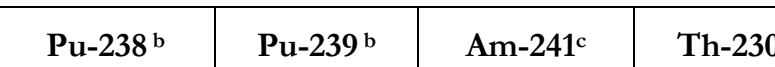

$0468 \mathrm{~S} 0030$

$0468 \mathrm{~S} 0031$

$0468 \mathrm{~S} 0032$

046850034

$0468 \mathrm{~S} 0035$

046850036

046850037

046850038

046850039

046850040

$0468 \mathrm{~S} 0041$

$0468 \mathrm{~S} 0042$

$0468 \mathrm{~S} 0043$

$0468 \mathrm{~S} 0044$

046850045

046850046

046850047

$0468 \mathrm{~S} 0048$

046850049

\begin{tabular}{l|c|c}
\hline-- & -- & 0.1 \\
\hline--- & ---1 & 0.1
\end{tabular}

$0.02 \pm 0.02$

Th-230

Ra-22

\begin{tabular}{l|l|l} 
& & $0.02 \pm 0.03$ \\
\hline $0.30 \pm 0.06$ & $0.00 \pm 0.01$ & $0.02 \pm 0.03$
\end{tabular}

$1.1 \pm 2.1$

$0.50 \pm 0.06$

$0.01 \pm 0.01$

$0.02 \pm 0.03$

$3.9 \pm 3.5$

$0.85+$

Th-232

$0.03 \pm 0.04$

$3.3 \pm 3.2$

$0.85 \pm 0.08$

$0.31 \pm 0.07$

U-238

$0.01 \pm 0.03$

$1.8 \pm 3.5$

$0.65 \pm 0.07$
$0.80 \pm 0.09$

$0.67 \pm 0.18$

$4.4 \pm 3.4$

$0.98 \pm 0.08$

$0.57 \pm 0.15$

$0.50 \pm 0.33$

U-235

$0.67 \pm 0.07$

$0.69 \pm 0.13$

$1.04 \pm 0.48$

$1.30 \pm 0.65$

$1.30 \pm 0.65$
$1.12 \pm 0.57$

$0.41 \pm 0.10$

$0.68 \pm 0.31$

$0.04 \pm 0.03$

$0.02 \pm 0.03$

\begin{tabular}{|c|c|}
\hline --- & --- \\
\hline --- & --- \\
\hline --- & --- \\
\hline
\end{tabular}

$-0.01 \pm 0.03$

$-1.1 \pm 3.2$

$0.80 \pm 0.08$

$\pm 0.19$

$1.53 \pm 0.56$

$1.6 \pm 3.1$

$-0.8 \pm 2.4$

$0.64 \pm 0.07$

$0.52 \pm 0.13$

$0.82 \pm 0.42$

$0.42 \pm 0.12$

$0.94 \pm 0.36$

$0.68 \pm 0.39$

\begin{tabular}{l|l}
$0.00+0.03$ & $2.2 \pm 2.9$ \\
\hline
\end{tabular}

\begin{tabular}{|l|l}
\hline $1.6 \pm 3.4$ & $1.17 \pm 0.10$ \\
\hline $0.3 \pm 3.7$ & $0.88 \pm 0.08$
\end{tabular}

$0.88 \pm 0.07$

$0.38 \pm 0.10$

$0.68 \pm 0.39$
$1.04 \pm 0.45$

$0.50 \pm 0.11$

$0.93 \pm 0.42$

$1.01 \pm 0.19$

$0.83 \pm 0.55$

$0.88 \pm 0.08$

$\begin{array}{ll}0.61 \pm 0.13 & 1.35 \pm 0.52\end{array}$

$4.2 \pm 3.8$

$0.01 \pm 0.04$

\begin{tabular}{l|l}
$0.07 \pm 0.03$ & $0.00 \pm 0.01$
\end{tabular}

$0.02 \pm 0.03$

$-0.8 \pm 2.8$

$-0.2 \pm 3.6$

$0.06 \pm 0.05$

$0.98 \pm 0.09$

$0.49 \pm 0.13$

$0.99 \pm 0.56$

$0.85 \pm 0.07$
$1.12 \pm 0.10$

$0.46 \pm 0.12$

$0.95 \pm 0.43$

$0.80 \pm 0.08$

$0.60 \pm 0.14$

$0.83 \pm 0.53$

$1.11 \pm 0.51$

$0.01 \pm 0.04$

$0.8 \pm 3.5$

$0.87 \pm 0.08$

$0.62 \pm 0.14$

$0.74 \pm 0.55$

$0.44 \pm 0.11$

$0.97 \pm 0.43$

$0.05 \pm 0.03$

$2.6 \pm 3.7$

$1.10+0.09$

$0.93 \pm 0.14$

$1.29 \pm 0.54$

$0.77 \pm 0.09$

$0.71 \pm 0.17$

$0.84 \pm 0.44$

\begin{tabular}{|c|c|c|c|}
\hline U-235 & Pb-210 & Pa-231 & Ac-227 \\
\hline $0.03 \pm 0.06$ & $0.68 \pm 0.26$ & $0.01 \pm 0.39$ & $0.04 \pm 0.09$ \\
\hline $0.10 \pm 0.12$ & $1.20 \pm 0.36$ & $0.00 \pm 0.65$ & $-0.03 \pm 0.16$ \\
\hline $0.12 \pm 0.08$ & $1.14 \pm 0.50$ & $-0.01 \pm 0.55$ & $-0.02 \pm 0.14$ \\
\hline $0.04 \pm 0.08$ & $0.92 \pm 0.54$ & $-0.22 \pm 0.64$ & $0.05 \pm 0.16$ \\
\hline $0.16 \pm 0.09$ & $1.02 \pm 0.48$ & $0.39 \pm 0.66$ & $0.05 \pm 0.17$ \\
\hline $0.08 \pm 0.06$ & $0.82 \pm 0.42$ & $0.09 \pm 0.42$ & $-0.01 \pm 0.11$ \\
\hline $0.02 \pm 0.10$ & $1.32 \pm 0.60$ & $-0.22 \pm 0.90$ & $0.00 \pm 0.19$ \\
\hline $0.08 \pm 0.12$ & $0.44 \pm 0.39$ & $0.47 \pm 0.55$ & $-0.05 \pm 0.15$ \\
\hline $0.06 \pm 0.08$ & $0.69 \pm 0.42$ & $0.04 \pm 0.65$ & $-0.06 \pm 0.14$ \\
\hline $0.10 \pm 0.09$ & $0.92 \pm 0.38$ & $0.17 \pm 0.61$ & $-0.01 \pm 0.13$ \\
\hline $0.02 \pm 0.10$ & $1.03 \pm 0.38$ & $-0.24 \pm 0.55$ & $0.06 \pm 0.14$ \\
\hline $0.07 \pm 0.09$ & $0.70 \pm 0.41$ & $-0.05 \pm 0.47$ & $0.11 \pm 0.12$ \\
\hline $0.06 \pm 0.13$ & $1.46 \pm 0.53$ & $0.92 \pm 0.84$ & $0.05 \pm 0.19$ \\
\hline $0.06 \pm 0.13$ & $0.62 \pm 0.48$ & $-0.17 \pm 0.57$ & $-0.10 \pm 0.15$ \\
\hline $0.08 \pm 0.13$ & $1.25 \pm 0.39$ & $-0.52 \pm 0.66$ & $0.16 \pm 0.17$ \\
\hline $0.06 \pm 0.09$ & $1.22 \pm 0.45$ & $-0.47 \pm 0.48$ & $0.11 \pm 0.14$ \\
\hline $0.10 \pm 0.10$ & $1.51 \pm 0.52$ & $-0.03 \pm 0.70$ & $-0.18 \pm 0.17$ \\
\hline $0.16 \pm 0.11$ & $1.08 \pm 0.52$ & $-0.25 \pm 0.63$ & $0.05 \pm 0.16$ \\
\hline $0.02 \pm 0.08$ & $1.03 \pm 0.53$ & $-0.40 \pm 0.65$ & $-0.11 \pm 0.17$ \\
\hline $0.10 \pm 0.08$ & $0.95 \pm 0.37$ & $0.25 \pm 0.67$ & $-0.08 \pm 0.15$ \\
\hline $0.12 \pm 0.09$ & $1.86 \pm 0.55$ & $-0.33 \pm 0.60$ & $0.08 \pm 0.15$ \\
\hline $0.11 \pm 0.13$ & $0.99 \pm 0.51$ & $0.36 \pm 0.63$ & $-0.11 \pm 0.16$ \\
\hline & & \multicolumn{2}{|c}{} \\
\hline
\end{tabular}

${ }^{a}$ Refer to figures 5 and 6 for sample locations.

${ }^{b} \mathrm{Pu}-238$ and $\mathrm{Pu}-239$ analysis by alpha spectroscopy.

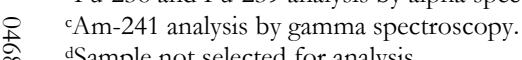

d Sample not selected for analysis.

is eUncertainties represent the $95 \%$ confidence level based on total propagated uncertainties. 
TABLE 4

RADIONUCLIDE CONCENTRATIONS IN JUDGMENTAL SOIL SAMPLES

OU-1 LANDFILL AREA

MOUND CLOSURE PROJECT

MIAMISBURG, OHIO

\begin{tabular}{|c|c|c|c|c|c|c|c|c|c|c|c|}
\hline \multirow{2}{*}{$\begin{array}{c}\text { ORISEa }^{\text {ORI }} \\
\text { Sample ID }\end{array}$} & \multicolumn{11}{|c|}{ Radionuclide Concentrations in Soil Samples (pCi/g) } \\
\hline & $\mathrm{Pu}-238^{\mathrm{b}}$ & $\mathrm{Pu}-239^{\mathrm{b}}$ & Am-241 & Th-230 & Ra-226 & Th-232 & $\mathrm{U}-238$ & $\mathrm{U}-235$ & $\mathrm{~Pb}-210$ & Pa-231 & Ac-227 \\
\hline $0468 \mathrm{~S} 0051$ & $3.47 \pm 0.30^{\circ}$ & $0.03 \pm 0.02$ & $\begin{array}{c}-0.05 \pm 0.10 \\
\end{array}$ & 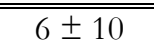 & $0.99 \pm 0.12$ & $20.6 \pm 1.6$ & $4.3 \pm 1.1$ & $0.12 \pm 0.18$ & $0.80 \pm 0.70$ & $0.4 \pm 1.6$ & $0.32 \pm 0.35$ \\
\hline $0468 \mathrm{~S} 0052$ & $3.87 \pm 0.34$ & $0.11 \pm 0.03$ & $0.02 \pm 0.03$ & $-0.2 \pm 3.0$ & $0.69 \pm 0.07$ & $0.82 \pm 0.14$ & $0.79 \pm 0.34$ & $0.08 \pm 0.11$ & $0.81 \pm 0.41$ & $0.41 \pm 0.54$ & $0.15 \pm 0.13$ \\
\hline $0468 \mathrm{~S} 0053$ & $0.36 \pm 0.34$ & $1.12 \pm 0.39$ & $82.6 \pm 4.7$ & $5.0 \pm 2.7$ & $0.86 \pm 0.08$ & $0.60 \pm 0.10$ & $0.43 \pm 0.30$ & $0.14 \pm 0.08$ & $4.4 \pm 1.3$ & $0.10 \pm 0.47$ & $0.04 \pm 0.12$ \\
\hline $0468 \mathrm{~S} 0054$ & $6.0 \pm 2.0$ & $790 \pm 110$ & $28.2 \pm 1.6$ & $1.3 \pm 2.0$ & $0.50 \pm 0.06$ & $0.23 \pm 0.08$ & $0.44 \pm 0.24$ & $0.06 \pm 0.07$ & $2.91 \pm 0.71$ & $0.23 \pm 0.37$ & $0.08 \pm 0.10$ \\
\hline $0468 \mathrm{~S} 0055$ & $0.43 \pm 0.07$ & $0.03 \pm 0.02$ & $0.03 \pm 0.03$ & $0.7 \pm 2.3$ & $0.54 \pm 0.06$ & $0.31 \pm 0.10$ & $0.42 \pm 0.32$ & $0.11 \pm 0.10$ & $0.53 \pm 0.36$ & $-0.19 \pm 0.47$ & $0.08 \pm 0.12$ \\
\hline $0468 \mathrm{~S} 0056$ & $0.05 \pm 0.02$ & $0.01 \pm 0.01$ & $-0.01 \pm 0.04$ & $1.9 \pm 3.1$ & $0.81 \pm 0.08$ & $0.93 \pm 0.14$ & $1.21 \pm 0.46$ & $0.09 \pm 0.09$ & $1.40 \pm 0.57$ & $0.22 \pm 0.61$ & $0.06 \pm 0.16$ \\
\hline
\end{tabular}

${ }^{a}$ Refer to figures 5 and 6 for sample locations.

${ }^{\mathrm{b}} \mathrm{Am}-241, \mathrm{Pu}-238$ and $\mathrm{Pu}-239$ analysis by alpha spectroscopy.

cUncertainties represent the $95 \%$ confidence level based on total propagated uncertainties 
TABLE 5

CHEMICAL CONCENTRATIONS IN SOIL

OU-1 LANDFILL

SURVEY UNIT 5 \& 6

MOUND CLOSURE PROJECT

MIAMISBURG, OHIO

\begin{tabular}{|c|c|c|c|c|c|c|c|c|c|c|c|c|c|c|}
\hline \multirow{2}{*}{$\begin{array}{c}\text { ORISE } \\
\text { Sample ID }\end{array}$} & \multicolumn{2}{|c|}{ Vinyl Chloride } & \multicolumn{2}{|c|}{ Chloroform } & \multicolumn{2}{|c|}{ Trichloroethene } & \multicolumn{2}{|c|}{ Toluene } & \multicolumn{2}{|c|}{ Tetrachloroethene } & \multicolumn{2}{|c|}{ Ethylbenzene } & \multicolumn{2}{|c|}{$\mathbf{P C B}^{\mathrm{d}}$} \\
\hline & $(\mathrm{mg} / \mathrm{kg})$ & Flag & $(\mathrm{mg} / \mathrm{kg})$ & Flag & $(\mathrm{mg} / \mathrm{kg})$ & Flag & $(\mathrm{mg} / \mathrm{kg})$ & Flag & $(\mathrm{mg} / \mathrm{kg})$ & Flag & $(\mathrm{mg} / \mathrm{kg})$ & Flag & $(\mathrm{mg} / \mathrm{kg})$ & Flag \\
\hline \multicolumn{15}{|l|}{ Survey Unit 5} \\
\hline 0468VOC-001 & 0.008 & $\mathrm{U}^{\mathrm{b}}$ & 0.004 & $\mathrm{U}$ & 0.006 & NFg & 0.001 & $J^{c}$ & 0.003 & $\mathrm{~J}$ & 0.004 & $\mathrm{U}$ & $4.5^{f}$ & $\mathrm{NF}$ \\
\hline 0468VOC-002 & 0.010 & $\mathrm{U}$ & 0.005 & $\mathrm{U}$ & 0.005 & $\mathrm{U}$ & 0.005 & $\mathrm{U}$ & 0.005 & $\mathrm{U}$ & 0.005 & $\mathrm{U}$ & 0.18 & $\mathrm{NF}$ \\
\hline 0468VOC-003 & 0.009 & $\mathrm{U}$ & 0.004 & $\mathrm{U}$ & 0.002 & $\mathrm{~J}$ & 0.0009 & $\mathrm{~J}$ & 0.004 & $\mathrm{NF}$ & 0.004 & $\mathrm{U}$ & 3.8 & NF \\
\hline 0468VOC-004 & 0.009 & $\mathrm{U}$ & 0.004 & $\mathrm{U}$ & 0.004 & $\mathrm{U}$ & 0.004 & $\mathrm{NF}$ & 0.004 & $\mathrm{U}$ & 0.001 & $\mathrm{~J}$ & 3.7 & $\mathrm{NF}$ \\
\hline 0468VOC-005 & 0.012 & $\mathrm{U}$ & 0.006 & $\mathrm{U}$ & 0.063 & $\mathrm{NF}$ & 0.003 & $\mathrm{~J}$ & 0.012 & $\mathrm{NF}$ & 0.006 & $\mathrm{U}$ & 1.7 & $\mathrm{NF}$ \\
\hline 0468VOC-006 & 0.012 & $\mathrm{U}$ & 0.006 & $\mathrm{U}$ & 0.006 & $\mathrm{U}$ & 0.002 & $\frac{J}{3}$ & 0.006 & $\mathrm{U}$ & 0.006 & $\mathrm{U}$ & $25^{f}$ & $\mathrm{NF}$ \\
\hline 0468VOC-007 & 0.008 & $\mathrm{U}$ & 0.004 & $\mathrm{U}$ & 0.004 & $\mathrm{U}$ & 0.001 & $\mathrm{~J}$ & 0.004 & $\mathrm{U}$ & 0.004 & $\mathrm{U}$ & 3.5 & $\mathrm{NF}$ \\
\hline 0468VOC-008 & 0.013 & $\mathrm{U}$ & 0.006 & $\mathrm{U}$ & 0.006 & $\mathrm{U}$ & 0.006 & $\mathrm{U}$ & 0.006 & $\mathrm{U}$ & 0.006 & $\mathrm{U}$ & 0.21 & $\mathrm{NF}$ \\
\hline 0468VOC-009 & 0.008 & $\mathrm{U}$ & 0.004 & $\mathrm{U}$ & 0.004 & $\mathrm{U}$ & 0.001 & $\mathrm{~J}$ & 0.004 & $\mathrm{U}$ & 0.004 & $\mathrm{U}$ & 1.7 & $\mathrm{NF}$ \\
\hline 0468VOC-010 & 0.009 & $\mathrm{U}$ & 0.004 & $\mathrm{U}$ & 0.0009 & $\mathrm{~J}$ & 0.002 & $\mathrm{~J}$ & 0.004 & $\mathrm{U}$ & 0.004 & $\mathrm{U}$ & 1.3 & $\mathrm{NF}$ \\
\hline 0468VOC-011 & 0.009 & $\mathrm{U}$ & 0.004 & $\mathrm{U}$ & 0.001 & J & 0.004 & $\mathrm{U}$ & 0.004 & $\mathrm{U}$ & 0.004 & $\mathrm{U}$ & $12^{\mathrm{f}}$ & $\mathrm{NF}$ \\
\hline 0468VOC-012 & 0.010 & $\mathrm{U}$ & 0.005 & $\mathrm{U}$ & 0.005 & $\mathrm{U}$ & 0.004 & $\mathrm{~J}$ & 0.005 & $\mathrm{U}$ & 0.001 & $\mathrm{~J}$ & 3.4 & $\mathrm{NF}$ \\
\hline 0468VOC-013 & 0.015 & $\mathrm{U}$ & 0.008 & $\mathrm{U}$ & 0.011 & $\mathrm{NF}$ & 0.003 & $\mathrm{~J}$ & 0.014 & $\mathrm{NF}$ & 0.008 & $\mathrm{U}$ & 0.078 & $\mathrm{NF}$ \\
\hline 0468VOC-014 & 0.009 & $\mathrm{U}$ & 0.004 & $\mathrm{U}$ & 0.001 & $J$ & 0.002 & $\frac{J}{J}$ & 0.002 & J & 0.004 & $\mathrm{U}$ & 0.36 & $\mathrm{NF}$ \\
\hline 0468VOC-015 & 0.009 & $\mathrm{U}$ & 0.004 & $\mathrm{U}$ & 0.002 & $\mathrm{~J}$ & 0.001 & $\mathrm{~J}$ & 0.004 & $\mathrm{U}$ & 0.004 & $\mathrm{U}$ & 2.6 & $\mathrm{NF}$ \\
\hline 0468VOC-016 & 0.009 & $\mathrm{U}$ & 0.005 & $\mathrm{U}$ & 0.005 & U & 0.005 & $\mathrm{U}$ & 0.005 & $\mathrm{U}$ & 0.005 & $\mathrm{U}$ & $19^{\mathrm{f}}$ & $\mathrm{NF}$ \\
\hline 0468VOC-017 & 0.010 & $\mathrm{U}$ & 0.005 & $\mathrm{U}$ & 0.005 & $\mathrm{U}$ & 0.005 & $\mathrm{U}$ & 0.005 & $\mathrm{U}$ & 0.005 & $\mathrm{U}$ & 0.38 & $\mathrm{NF}$ \\
\hline 0468VOC-018 & 0.010 & $\mathrm{U}$ & 0.005 & $\mathrm{U}$ & 0.027 & $\mathrm{NF}$ & 0.003 & $\mathrm{~J}$ & 0.069 & $\mathrm{NF}$ & 0.005 & $\mathrm{U}$ & 0.0077 & $\mathrm{~J}$ \\
\hline 0468VOC-019 & 0.010 & $\mathrm{U}$ & 0.005 & $\mathrm{U}$ & 0.001 & $\mathrm{~J}$ & 0.009 & $\mathrm{NF}$ & 0.005 & $\mathrm{NF}$ & 0.003 & $\mathrm{~J}$ & 0.049 & $\mathrm{NF}$ \\
\hline 0468VOC-020 & 0.009 & $\mathrm{U}$ & 0.001 & $\mathrm{~J}$ & 1.4 & $\mathrm{NF}$ & 0.003 & $\mathrm{~J}$ & 4.200 & $\mathrm{E}^{\mathrm{e}}$ & 0.005 & $\mathrm{U}$ & 2.7 & $\mathrm{NF}$ \\
\hline 0468VOC-021 & 0.009 & $\mathrm{U}$ & 0.015 & $\mathrm{NF}$ & 0.002 & $\mathrm{~J}$ & 0.005 & $\mathrm{U}$ & 0.002 & $\mathrm{~J}$ & 0.005 & $\mathrm{U}$ & 2.7 & $\mathrm{NF}$ \\
\hline 0468VOC-022 & 0.014 & $\mathrm{U}$ & 0.007 & $\mathrm{U}$ & 0.007 & $\mathrm{U}$ & 0.007 & $\mathrm{U}$ & 0.007 & $\mathrm{U}$ & 0.007 & $\mathrm{U}$ & 0.52 & $\mathrm{NF}$ \\
\hline 0468VOC-023 & 0.009 & $\mathrm{U}$ & 0.004 & $\mathrm{U}$ & 0.004 & $\mathrm{NF}$ & 0.003 & $\mathrm{~J}$ & 0.038 & $\mathrm{NF}$ & 0.001 & $\mathrm{~J}$ & 0.015 & $\mathrm{U}$ \\
\hline 0468VOC-024 & 0.010 & $\mathrm{U}$ & 0.005 & $\mathrm{U}$ & 0.005 & $\mathrm{U}$ & 0.002 & $\mathrm{~J}$ & 0.005 & $\mathrm{U}$ & 0.005 & $\mathrm{U}$ & 0.0067 & $\mathrm{~J}$ \\
\hline 0468VOC-025 & 0.008 & $\mathrm{U}$ & 0.004 & $\mathrm{U}$ & 0.004 & $\mathrm{U}$ & 0.004 & $\mathrm{U}$ & 0.004 & $\mathrm{U}$ & 0.004 & $\mathrm{U}$ & 0.039 & $\mathrm{NF}$ \\
\hline \multicolumn{15}{|l|}{ Survey Unit 6} \\
\hline 0468VOC-026 & 0.010 & $\mathrm{U}$ & 0.005 & $\mathrm{U}$ & 0.005 & U & 0.001 & $\mathrm{~J}$ & 0.005 & $\mathrm{U}$ & 0.005 & $\mathrm{U}$ & $--^{-h}$ & --- \\
\hline 0468VOC-027 & 0.011 & $\mathrm{U}$ & 0.006 & $\mathrm{U}$ & 0.006 & $\mathrm{U}$ & 0.007 & $\mathrm{NF}$ & 0.006 & $\mathrm{U}$ & 0.002 & $\mathrm{~J}$ & --- & --- \\
\hline 0468VOC-028 & 0.010 & $\mathrm{U}$ & 0.005 & $\mathrm{U}$ & 0.002 & $\mathrm{~J}$ & 0.005 & $\mathrm{U}$ & 0.001 & $\mathrm{~J}$ & 0.005 & $\mathrm{U}$ & --- & --- \\
\hline 0468VOC-029 & 0.011 & $\mathrm{U}$ & 0.006 & $\mathrm{U}$ & 0.004 & $\frac{J}{5}$ & 0.005 & $\mathrm{~J}$ & 0.006 & $\mathrm{U}$ & 0.002 & $\mathrm{~J}$ & --- & --- \\
\hline 0468VOC-030 & 0.010 & $\mathrm{U}$ & 0.005 & $\mathrm{U}$ & 0.003 & $\bar{J}$ & 0.003 & $\mathrm{~J}$ & 0.005 & $\mathrm{U}$ & 0.005 & $\mathrm{U}$ & --- & $\overline{---}$ \\
\hline
\end{tabular}


TABLE 5

CHEMICAL CONCENTRATIONS IN SOIL

OU-1 LANDFILL

SURVEY 5 \& 6

MOUND CLOSURE PROJECT

MIAMISBURG, OHIO

(continued)

\begin{tabular}{|c|c|c|c|c|c|c|c|c|c|c|c|c|c|c|}
\hline \multirow{2}{*}{$\begin{array}{c}\text { ORISE }^{a} \\
\text { Sample ID }\end{array}$} & \multicolumn{2}{|c|}{ Vinyl Chloride } & \multicolumn{2}{|c|}{ Chloroform } & \multicolumn{2}{|c|}{ Trichloroethene } & \multicolumn{2}{|c|}{ Toluene } & \multicolumn{2}{|c|}{ Tetrachloroethene } & \multicolumn{2}{|c|}{ Ethylbenzene } & \multicolumn{2}{|c|}{$\mathbf{P C B}^{\mathrm{d}}$} \\
\hline & $(\mathrm{mg} / \mathrm{kg})$ & Flag & $(\mathrm{mg} / \mathrm{kg})$ & Flag & $(\mathrm{mg} / \mathrm{kg})$ & Flag & $(\mathrm{mg} / \mathrm{kg})$ & Flag & $(\mathrm{mg} / \mathrm{kg})$ & Flag & $(\mathrm{mg} / \mathrm{kg})$ & Flag & $(\mathrm{mg} / \mathrm{kg})$ & Flag \\
\hline 0468VOC-031 & 0.008 & $\mathrm{U}$ & 0.004 & $\mathrm{U}$ & 0.006 & $\mathrm{NF}$ & 0.0009 & $\mathrm{~J}$ & 0.004 & $\mathrm{U}$ & 0.004 & $\mathrm{U}$ & --- & +-- \\
\hline 0468VOC-032 & 0.008 & $\mathrm{U}$ & 0.004 & $\mathrm{U}$ & 0.006 & $\mathrm{NF}$ & 0.002 & $\mathrm{~J}$ & 0.004 & $\mathrm{U}$ & 0.004 & $\mathrm{U}$ & --- & --- \\
\hline 0468VOC-033 & 0.010 & $\mathrm{U}$ & 0.005 & $\mathrm{U}$ & 0.012 & $\mathrm{NF}$ & 0.002 & $\mathrm{~J}$ & 0.002 & $\mathrm{~J}$ & 0.005 & $\mathrm{U}$ & --- & --- \\
\hline 0468VOC-034 & 0.008 & $\mathrm{U}$ & 0.004 & $\mathrm{U}$ & 0.004 & $\mathrm{NF}$ & 0.002 & $\mathrm{~J}$ & 0.004 & $\mathrm{U}$ & 0.004 & $\mathrm{U}$ & --- & --- \\
\hline 0468VOC-035 & 0.009 & $\mathrm{U}$ & 0.004 & $\mathrm{U}$ & 0.023 & $\mathrm{NF}$ & 0.002 & $\mathrm{~J}$ & 0.007 & $\mathrm{NF}$ & 0.004 & $\mathrm{U}$ & --- & --- \\
\hline 0468VOC-036 & 0.008 & $\mathrm{U}$ & 0.004 & $\mathrm{U}$ & 0.010 & NF & 0.001 & $\mathrm{~J}$ & 0.004 & $\mathrm{U}$ & 0.004 & $\mathrm{U}$ & --- & --- \\
\hline 0468VOC-036D & 0.009 & $\mathrm{U}$ & 0.004 & $\mathrm{U}$ & 0.007 & $\mathrm{NF}$ & 0.001 & $\mathrm{~J}$ & 0.004 & $\mathrm{U}$ & 0.004 & $\mathrm{U}$ & --- & --- \\
\hline 0468VOC-037 & 0.010 & $\mathrm{U}$ & 0.005 & $\mathrm{U}$ & 0.004 & $\mathrm{~J}$ & 0.008 & $\mathrm{NF}$ & 0.005 & $\mathrm{U}$ & 0.002 & $\mathrm{~J}$ & --- & --- \\
\hline 0468VOC-038 & 0.008 & $\mathrm{U}$ & 0.004 & $\mathrm{U}$ & 0.004 & $\mathrm{U}$ & 0.0008 & $\mathrm{~J}$ & 0.004 & $\mathrm{U}$ & 0.004 & $\mathrm{U}$ & --- & --- \\
\hline 0468VOC-039 & 0.010 & $\mathrm{U}$ & 0.005 & $\mathrm{U}$ & 0.011 & $\mathrm{NF}$ & 0.013 & $\mathrm{NF}$ & 0.015 & $\mathrm{NF}$ & 0.004 & $\mathrm{~J}$ & --- & --- \\
\hline 0468VOC-040 & 0.008 & $\mathrm{U}$ & 0.004 & $\mathrm{U}$ & 0.003 & $\mathrm{~J}$ & 0.004 & NF & 0.004 & $\mathrm{U}$ & 0.004 & $\mathrm{U}$ & --- & --- \\
\hline 0468VOC-041 & 0.010 & $\mathrm{U}$ & 0.005 & $\mathrm{U}$ & 0.005 & $\mathrm{U}$ & 0.005 & $\mathrm{U}$ & 0.005 & $\mathrm{U}$ & 0.005 & $\mathrm{U}$ & --- & --- \\
\hline 0468VOC-042 & 0.008 & $\mathrm{U}$ & 0.004 & $\mathrm{U}$ & 0.002 & $\mathrm{~J}$ & 0.001 & $\mathrm{~J}$ & 0.004 & $\mathrm{U}$ & 0.004 & $\mathrm{U}$ & --- & --- \\
\hline 0468VOC-043 & 0.008 & $\mathrm{U}$ & 0.004 & $\mathrm{U}$ & 0.004 & $\mathrm{U}$ & 0.004 & $\mathrm{U}$ & 0.004 & $\mathrm{U}$ & 0.004 & $\mathrm{U}$ & --- & --- \\
\hline 0468VOC-044 & 0.010 & $\mathrm{U}$ & 0.005 & $\mathrm{U}$ & 0.005 & $\mathrm{U}$ & 0.004 & $\mathrm{~J}$ & 0.005 & $\mathrm{U}$ & 0.001 & $\mathrm{~J}$ & --- & --- \\
\hline 0468VOC-045 & 0.009 & $\mathrm{U}$ & 0.004 & $\mathrm{U}$ & 0.003 & $\mathrm{~J}$ & 0.002 & $\mathrm{~J}$ & 0.004 & $\mathrm{U}$ & 0.004 & $\mathrm{U}$ & --- & --- \\
\hline 0468VOC-046 & 0.008 & $\mathrm{U}$ & 0.004 & $\mathrm{U}$ & 0.004 & $\mathrm{U}$ & 0.004 & $\mathrm{U}$ & 0.004 & $\mathrm{U}$ & 0.004 & $\mathrm{U}$ & --- & --- \\
\hline 0468VOC-047 & 0.009 & $\mathrm{U}$ & 0.004 & $\mathrm{U}$ & 0.004 & $\mathrm{U}$ & 0.001 & $\mathrm{~J}$ & 0.004 & $\mathrm{U}$ & 0.004 & $\mathrm{U}$ & --- & --- \\
\hline 0468VOC-048 & 0.009 & $\mathrm{U}$ & 0.005 & $\mathrm{U}$ & 0.005 & $\mathrm{U}$ & 0.003 & $\mathrm{~J}$ & 0.005 & $\mathrm{U}$ & 0.005 & $\mathrm{U}$ & --- & --- \\
\hline 0468VOC-049 & 0.010 & $\mathrm{U}$ & 0.005 & $\mathrm{U}$ & 0.001 & $\mathrm{~J}$ & 0.002 & $\mathrm{~J}$ & 0.005 & $\mathrm{U}$ & 0.005 & $\mathrm{U}$ & --- & --- \\
\hline 0468VOC-050 & 0.009 & $\mathrm{U}$ & 0.004 & $\mathrm{U}$ & 0.004 & $\mathrm{U}$ & 0.001 & $\mathrm{~J}$ & 0.004 & $\mathrm{U}$ & 0.004 & $\mathrm{U}$ & $\begin{array}{ll}--- \\
\end{array}$ & $\begin{array}{ll}--- \\
\end{array}$ \\
\hline
\end{tabular}

aRefer to Figures 6 and 7 for sample location.

$\mathrm{b} \mathrm{U}=$ Compound analyzed but not detected.

$\mathrm{c}=$ Compound present below detection limit.

dPCB COC for Survey Unit 5 only.

${ }^{\mathrm{e}} \mathrm{E}=$ Compound identified beyond the calibration range and was subsequently analyzed at dilution.

\& ${ }^{\mathrm{f}}$ Exceeds the CO.

is $\mathrm{gNF}=$ No Flag.

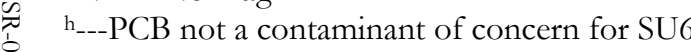




\section{REFERENCES}

Accelerated Remediation Company (ARC). The Response Action Plan for the Operable Unit One (OU-1) Landfill Area at the Miamisburg Closure Project. Miamisburg, OH; July 2006.

Accelerated Remediation Company. Soils Verification Sampling and Analysis Plan Mound Operable Unit 1 Landfill Area. Miamisburg, OH; January 2007a.

Accelerated Remediation Company. Response to ORISE Comments, Miamisburg, OH; June 2007b.

Accelerated Remediation Company. Partial 1 Post-Excavation Survey Unit Design Survey Units 1, 2, 3, 4, 5, and 6 only OU-1 Landfill Project Miamisburg, OH, October 2, 2007c.

BWXT of Ohio, Inc. (BWXTO). Work Plan for Environmental Restoration of the DOE Mound Site, The Mound 2000 Approach. Revision 0. Miamisburg, OH; February 1999.

DeNuke Services (DNS). Electronic mail from C. Gerbig (DNS) to P. Weaver (ORISE), OU-1 FVS Results; December 19, 2007.

Mound Environmental Restoration Program (MERP). Mound 2000 Residual Risk Evaluation Methodology. Revision 0. Miamisburg, OH; January 6, 1997.

Oak Ridge Associated Universities (ORAU). Quality Program Manual for the Independent Environmental Assessment and Verification Program. Oak Ridge, Tennessee; November 1, 2007.

Oak Ridge Institute for Science and Education (ORISE). Survey Procedures Manual for the Independent Environmental Assessment and Verification Program. Oak Ridge, Tennessee; November 1, 2007a.

Oak Ridge Institute for Science and Education. Comments on the Verification Sampling \& Analysis Plan and Supporting Procedures for Area OU-1 Miamisburg Closure Project Miamisburg, Ohio. Oak Ridge, Tennessee; April 30, 2007b.

Oak Ridge Institute for Science and Education. Final Project-Specific Plan for The Independent Verification Of Areas OU-1 And PRS 441 At The Department Of Energy Miamisburg Closure Project, Miamisburg, Ohio. Oak Ridge, Tennessee; April 11, 2007c.

Oak Ridge Institute for Science and Education. Laboratory Procedures Manual for the Independent Environmental Assessment and Verification Program. Oak Ridge, Tennessee; November 1, 2007d.

Oak Ridge Institute for Science and Education. Revision: In-Process Inspection Report For The Miamisburg Closure Project Operable Unit-1 Landfill, Miamisburg, Ohio. Oak Ridge, Tennessee; December 24, 2007e.

U.S. Department of Energy (DOE). Environment, Safety and Health Bulletin: A Guide to Good Practices for the Control and Release of Property. DOE/EH-0697. Washington, DC. July 2006.

U.S. Department of Energy. Electronic mail from P. Lucas (DOE) to P. Weaver (ORISE), Reply: Revision to OU-1 Inspection Report; December 10, 2007. 


\section{REFERENCES \\ (continued)}

U.S. Environmental Protection Agency (EPA). Data Quality Assessment: Statistical Methods for Practitioners. EPA QA/G-9S; Washington, DC. February 2006.

U.S. Environmental Protection Agency. Test Methods for Evaluating Solid Waste EPA SW-846, Washington, DC. February 2007.

U.S. Nuclear Regulatory Commission (NRC). Multi-Agency Survey and Site Investigation Manual (MARSSIM), NUREG-1575; Revision 1, Washington, DC. August 2000. 
APPENDIX A

MAJOR INSTRUMENTATION 


\section{APPENDIX A}

\section{MAJOR INSTRUMENTATION}

The display of a specific product is not to be construed as an endorsement of the product or its manufacturer by the author or her employer.

\section{SCANNING INSTRUMENT/DETECTOR COMBINATIONS}

\section{LABORATORY ANALYTICAL INSTRUMENTATION}

Alpha Spectrometry System

Tennelec Model 256

(Canberra, Meriden, CT)

Used in conjunction with:

Ion Implanted Detectors

(Canberra, Meriden, CT) and

Multichannel Analyzer

DEC ALPHA Workstation

(Canberra, Meriden, CT)

Alpha Spectrometry System Canberra Model 7401VR

(Canberra, Meriden, CT)

Used in conjunction with:

Ion Implanted Detectors and

Multichannel Analyzer

DEC ALPHA Workstation

(Canberra, Meriden, CT)

High Purity Extended Range Intrinsic Detector

CANBERRA/Tennelec Model No: ERVDS30-25195

(Canberra, Meriden, CT)

Used in conjunction with:

Lead Shield Model G-11

(Nuclear Lead, Oak Ridge, TN) and

Multichannel Analyzer

DEC ALPHA Workstation

(Canberra, Meriden, CT) 
High Purity Extended Range Intrinsic Detector Model No. GMX-45200-5

(AMETEK/ORTEC, Oak Ridge, TN)

used in conjunction with:

Lead Shield Model SPG-16-K8

(Nuclear Data)

Multichannel Analyzer

DEC ALPHA Workstation

(Canberra, Meriden, CT)

High-Purity Germanium Detector

Model GMX-30-P4, 30\% Eff.

(AMETEK/ORTEC, Oak Ridge, TN)

Used in conjunction with:

Lead Shield Model G-16

(Gamma Products, Palos Hills, IL) and

Multichannel Analyzer

DEC ALPHA Workstation

(Canberra, Meriden, CT) 
APPENDIX B

SURVEY AND ANALYTICAL PROCEDURES 


\section{APPENDIX B}

\section{SURVEY AND ANALYTICAL PROCEDURES}

\section{Project Health AND SAFETy}

The survey and sampling procedures were evaluated to ensure that any hazards inherent to the procedures themselves were addressed in current job hazard analyses (JHAs). All survey and laboratory activities were conducted in accordance with ORISE health and safety and radiation protection procedures.

Pre-survey activities included an overview of potential health and safety issues. Representatives with the Accelerated Remediation Company provided site-specific safety awareness at for each individual ORISE survey effort. In-process and verification surveys were performed according to the ORISE generic health and safety plan, site-specific integrated safety management (ISM) pre-job hazard checklist, and safety procedures discussed during the on-site training.

\section{QUALITY ASSURANCE}

Analytical and field survey activities were conducted in accordance with procedures from the following ORAU and ORISE documents:

- $\quad$ Survey Procedures Manual

- $\quad$ Laboratory Procedures Manual

- Quality Program Manual

The procedures contained in these manuals were developed to meet the requirements of DOE Order 414.1C and the U.S. Nuclear Regulatory Commission Quality Assurance Manual for the Office of Nuclear Material Safety and Safeguards and contain measures to assess processes during their performance.

Quality control procedures include:

- Daily instrument background and check-source measurements to confirm that equipment operation is within acceptable statistical fluctuations. 
- Participation in MAPEP, NRIP, and ITP Laboratory Quality Assurance Programs.

- Training and certification of all individuals performing procedures.

- Periodic internal and external audits.

\section{CALIBRATION}

Calibration of all field and laboratory instrumentation was based on standards/sources, traceable to the National Institute of Standards and Technology (NIST), when such standards/sources were available. In cases where they were not available, standards of an industry-recognized organization were used.

\section{SURVEY PROCEDURES}

\section{$\underline{\text { Surface Scans }}$}

Scans for elevated gamma radiation were performed by passing the detector slowly over the surface. The distance between the detector and surface was maintained at a nominal of about 1 to $5 \mathrm{~cm}$. A $\mathrm{NaI}$ scintillation detector and a low-energy photon FIDLER detector with a detector area $127 \mathrm{~cm}^{2}$ were coupled to GPS units that enabled real-time recording of position in one-second intervals. Identification of elevated radiation levels was based on increases in the audible signal from the instrument. Positioning data files were downloaded from field data loggers for plotting using commercially available software (http://trl.trimble.com/docushare/dsweb/Get/Document261826/GeoExpl2005 100A GSG ENG.pdf).

The scan minimum detectable concentrations (MDCs) for the NaI scintillation detector for the contaminants of concern in surface soil were obtained directly from NUREG-1507 when available or estimated using the calculation approach described in NUREG-1507 ${ }^{1}$. A typical NaI detector MDC for Am-241 is $44.6 \mathrm{pCi} / \mathrm{g}, 2.8 \mathrm{pCi} / \mathrm{g}$ for Th-232, $60 \mathrm{pCi} / \mathrm{g}$ for U-238, and $115 \mathrm{pCi} / \mathrm{g}$ for natural Uranium. ORISE used the FIDLER for qualitative measurements. An audible increase in the activity rate was investigated by ORISE. It is standard procedure for the ORISE staff to pause and investigate any locations where gamma radiation is distinguishable from background levels.

${ }^{1}$ NUREG-1507. Minimum Detectable Concentrations With Typical Radiation Survey Instruments for Various Contaminants and Field Conditions. U.S. Nuclear Regulatory Commission. Washington, DC; June 1998. 


\section{Soil Sampling}

Approximately 0.5 to $1 \mathrm{~kg}$ of soil was collected at each sample location. Collected samples were placed in plastic bags, sealed, and labeled in accordance with ORISE survey procedures.

\section{RADIOLOGICAL ANALYSIS}

\section{DETECTION LIMITS}

Detection limits, referred to as MDC, were based on 3 plus 4.65 times the standard deviation of the background count $\left[3+\left(4.65(B K G)^{1 / 2}\right)\right]$. Because of variations in background levels, measurement efficiencies, and contributions from other radionuclides in samples, the detection limits differ from sample to sample and instrument to instrument.

\section{Alpha Spectroscopy}

Soil samples were homogenized then dissolved by a combination of potassium hydrogen fluoride and pyrosulfate fusions. The fusion cakes are dissolved and all alpha emitters are co-precipitated on barium sulfate. The barium sulfate is re-dissolved and the COC is separated from the other actinides by extraction chromatography using Eichrom resins, re-precipitated with a cerium fluoride carrier, and analyzed using ion implanted detectors, alpha spectrometers, and multichannel analyzer.

An alpha spectroscopy detector system calculates an MDC for each individual isotope per sample based on the detector background, counting efficiency, yield, and quantity. An MDC is printed out with each sample results. The typical MDC for a 1000 -minute count time was $0.02 \mathrm{pCi} / \mathrm{g}$.

\section{Gamma Spectroscopy}

Samples of soil were dried, mixed, crushed, and/or homogenized as necessary, and a portion sealed in a 0.5 -liter Marinelli beaker or other appropriate container. The quantity placed in the beaker was chosen to reproduce the calibrated counting geometry. Net material weights were determined and the samples counted using intrinsic germanium detectors coupled to a pulse height analyzer system. Background and Compton stripping, peak search, peak identification, and concentration calculations were performed using the computer capabilities inherent in the analyzer system. All total absorption peaks (TAP) associated with the radionuclides of concern were reviewed for consistency of activity. 
Total absorption peaks used for determining the activities of radionuclides of concern and the typical associated MDCs for a one-hour count time were:

\begin{tabular}{|c|c|c|}
\hline Radionuclide & TAP (MeV) & MDC (pCi/g) \\
\hline \hline U-238 (from Th-234) & 0.063 & 0.21 \\
\hline U-235 & 0.143 & 0.06 \\
\hline Am-241 & 0.059 & 0.06 \\
\hline Pa-231 & 0.284 & 1.1 \\
\hline Ra-226 (from Pb-214) & 0.351 & 0.19 \\
\hline Pb-210 & 0.046 & 0.54 \\
\hline Th-230 & 0.228 & 0.05 \\
\hline Th-232 (from Ac-228) & 0.911 & 0.05 \\
\hline Ac-227 (from Th-227) & 0.256 & 0.05 \\
\hline
\end{tabular}

Spectra were also reviewed for other identifiable TAPs.

\section{Uncertainties}

The uncertainties associated with the analytical data presented in the tables of this report represent the total propagated uncertainties for that data. These uncertainties were calculated based on both the gross sample count levels and the associated background count levels. 
APPENDIX C

DATA QUALIFIERS FOR CHEMICAL RESULTS 


\section{APPENDIX C \\ DATA QUALIFIERS FOR CHEMICAL RESULTS}

\section{DATA QUALIFIERS}

$\mathbf{U}=$ Compound was analyzed for but not detected. The associated numerical value is the estimated sample quantitation limit which is included and corrected for dilution and percent moisture.

$\mathbf{J}=$ Indicates an estimated value. This flag is used under the following circumstances 1) when estimating a concentration for tentatively identified compounds (TICs) where a 1:1 response is assumed; or 2) when the mass spectral data indicate the presence of a compound that meets the identification criteria but the result is less than the specified detection limit but greater than zero. For example, if the limit of detection is $10 \mu \mathrm{g} / \mathrm{L}$ and a concentration of $3 \mu \mathrm{g} / \mathrm{L}$ is calculated, it is reported as $3 \mathrm{~J}$.

$\mathbf{B}=$ This flag is used when the analyte is found in the associated blank as well as in the sample. It indicates possible/probable blank contamination. This flag is also used for a TIC as well as for positively identified TCL compound.

$\mathbf{E}=$ Indicates that the compound was detected beyond the calibration range and was subsequently analyzed at a dilution.

D = Identifies all compounds identified in an analysis at a secondary dilution factor.

$\mathbf{I}=$ Interference.

$\mathbf{N Q}=$ Result qualitatively confirmed but not able to quantify.

$\mathbf{N}=$ Indicates presumptive evidence of a compound. This flag is only used for tentatively identified compounds (TICs), where the identification is based on a mass spectral library search. It is applied to all TIC results. For generic characterization of a TIC, such as chlorinated hydrocarbon, the $\mathrm{N}$ code is not used.

$\mathbf{X}=$ This flag is used for a TIC compound which is quantified relative to a response factor generated from a daily calibration standard (rather than quantified relative to the closest internal standard).

$\mathbf{Y}=$ Additional qualifiers used as required are explained in the case narrative.

*Adapted from Lionville Laboratory, Inc TCE Analytical Data Package. 
APPENDIX D

STATISTICAL SURVEY DESIGN FOR THE OU-1 LANDFILL 


\section{APPENDIX D}

\section{STATISTICAL SURVEY DESIGN FOR THE OU-1 LANDFILL}

\section{SuRVEY DESIGN SUMMARY}

ORISE used available pre-final status survey data to develop a defensible statistical sampling and survey design for SUs 5 and 6. The parametric One-Sample Proportion Test was selected as a means to test for the difference between a population proportion, $P$, and a fixed threshold $\left(P_{0}\right)$ (EPA 2006). The VSP software was used to calculate the number of samples required to reject the null hypothesis in favor of the alternative given a selected sampling approach and inputs to the equation (VSP version 5,2007$)$. The primary purpose is to compare a proportion of values that exceed a given threshold with specified threshold proportion or Cleanup Objective. The design assumes that the null hypothesis is that proportion of sample exceedences that will be less than the threshold and the alternative hypothesis would be equal to or exceeds the threshold.

$P_{0}=0.5$, this test is equivalent to the Sign test.

Data: A simple or systematic random sample, $x 1, \ldots, x n$, from the population of interest.

Assumptions: The data constitutes an independent random sample from the population.

Limitations and Robustness: Both $n P_{0}$ and $n\left(1-P_{0}\right)$ must be at least 5 to apply the normal approximation. Otherwise, exact tests must be used and a statistician should be consulted. (EPA 2006).

\section{Determination Of Number Of Data Points}

\section{Number of Total Samples: Calculation Equation and Inputs}

The equation used to calculate the number of samples is based on the large sample approximation of the binomial distribution. For this site, the null hypothesis is rejected in favor of the alternative one if the sample proportion is sufficiently larger than the threshold. The number of samples to collect is calculated so that if the inputs to the equation are true, the calculated number of samples will cause the null hypothesis to be rejected.

The formula used to calculate the number of samples is:

$$
n=\left[\frac{z_{1-\alpha} \sqrt{P_{0}\left(1-P_{0}\right)}+z_{1-\beta} \sqrt{P_{0}\left(1-P_{0}\right)}}{2}\right]
$$

where:

$n \quad$ is the number of samples,

$P_{0} \quad$ is the threshold,

$P_{1} \quad$ is the outer bound of the grey region (note that $\left|P_{1-} P_{0}\right|$ is the width of the gray region $\Delta$ ),

$\alpha \quad$ in the acceptable probability of incorrectly concluding the proportion of exceedences exceeds the threshold,

$B$ is the acceptable probability of incorrectly concluding the proportion of exceedences is less than the threshold, 
$\mathrm{Z}_{1-\alpha} \quad$ is the value of the standard normal distribution such that the proportion of the distribution less than $Z_{1-\alpha}-1_{\alpha}$ $Z_{1-\beta} \quad$ is the value of the standard normal distribution such that the proportion of the distribution less than $Z_{1-\beta}-1_{\beta}$. The values of these inputs that result in the calculated number of sampling locations are:

\begin{tabular}{|l|l|}
\hline Parameter & Value \\
\hline$P_{0}$ & 0.9 \\
\hline$P_{1}$ & 1 \\
\hline$\alpha$ & $5 \%$ \\
\hline$B$ & $5 \%$ \\
\hline$z_{1-\alpha}$ & $1.64485^{\mathrm{a}}$ \\
\hline$z_{1-\beta}$ & $1.64485^{\mathrm{b}}$ \\
\hline
\end{tabular}

${ }^{a}$ This value is automatically calculated by VSP based upon the user defined value of $\alpha$. ${ }^{\mathrm{b}}$ This value is automatically calculated by VSP based upon the user defined value of $B$.

\section{Statistical Assumptions}

The assumptions associated with the formulas for computing the number of samples are:

1. the population values are not spatially or temporally correlated, and

2. the sampling locations will be selected probabilistically.

The first assumption will be assessed in a post data collection analysis. The last assumption is valid because the gridded sample locations were selected on a random start.

\section{Sensitivity Analysis}

The sensitivity of the calculation of number of samples was explored by varying the alpha (\%), probability of mistakenly concluding that $p>$ action level and examining the resulting changes in the number of samples. The following table shows the results of this analysis

\begin{tabular}{|l|r|r|r|}
\hline & $\boldsymbol{\beta = 5}$ & $\boldsymbol{\beta = 1 0}$ & $\boldsymbol{\beta = 1 5}$ \\
\hline $\boldsymbol{\alpha = 5}$ & 25 & 25 & 25 \\
\hline $\boldsymbol{\alpha = 1 0}$ & 15 & 15 & 15 \\
\hline $\boldsymbol{\alpha = 1 5}$ & 10 & 10 & 10 \\
\hline
\end{tabular}

$\alpha=$ Alpha (\%), Probability of mistakenly concluding that $P>$ action level

$\beta=$ Beta (\%), Probability of mistakenly concluding that $P<$ action level

Because the primary objective for sampling for this site is to compare the site proportion of exceedences with a threshold value, the data will be assessed in this context. Assuming the data are adequate, at least one statistical test will be done to perform a comparison between the data and the threshold of interest. Results of the exploratory and quantitative assessments of the data will be reported, along with conclusions that may be supported by them. 